\title{
Sensory Axon-Derived Neuregulin-1 Is Required for Axoglial Signaling and Normal Sensory Function But Not for Long- Term Axon Maintenance
}

\author{
Florence R. Fricker, ${ }^{1}$ Ning Zhu, ${ }^{1}$ Christoforos Tsantoulas, ${ }^{1}$ Bjarke Abrahamsen, ${ }^{2}$ Mohammed A. Nassar, ${ }^{2}$ \\ Matthew Thakur, ${ }^{1}$ Alistair N. Garratt, ${ }^{3}$ Carmen Birchmeier, ${ }^{3}$ Stephen B. McMahon, ${ }^{1}$ John N. Wood, ${ }^{2}$ and \\ David L. H. Bennett ${ }^{1}$ \\ ${ }^{1}$ Wolfson Centre for Age-Related Diseases, King's College London, Guy's Campus, London SE1 1UL, United Kingdom, ${ }^{2}$ Molecular Nociception Group, \\ University College London, London WC1E6BT, United Kingdom, and ${ }^{3}$ Max Delbrueck Center for Molecular Medicine, 13092 Berlin, Germany
}

\begin{abstract}
Neuregulin-1 has a key role in mediating signaling between axons and Schwann cells during development. A limitation to studying its role in adulthood is the embryonic lethality of global Nrg1 gene deletion. We used the Cre-loxP system to generate transgenic mice in which neuregulin-1 is conditionally ablated in the majority of small-diameter and a proportion of large-diameter sensory neurons that have axons conducting in the $\mathrm{C}$ - and $\mathrm{A} \delta$-fiber range, respectively. Sensory neuron-specific neuregulin-1 ablation resulted in abnormally large Remak bundles with axons clustered in "polyaxonal" pockets. The total number of axons in the sural nerve was unchanged, but a greater proportion was unmyelinated. In addition, we observed large-diameter axons that were in a 1:1 relationship with Schwann cells, surrounded by a basal lamina but not myelinated. There was no evidence of DRG or Schwann cell death; the markers of different DRG cell populations and cutaneous innervation were unchanged. These anatomical changes were reflected in a slowing of conduction velocity at the lower end of the A-fiber conduction velocity range and a new population of more rapidly conducting C-fibers that are likely to represent large-diameter axons that have failed to myelinate. Conditional neuregulin-1 ablation resulted in a reduced sensitivity to noxious mechanical stimuli. These findings emphasize the importance of neuregulin-1 in mediating the signaling between axons and both myelinating and nonmyelinating Schwann cells required for normal sensory function. Sensory neuronal survival and axonal maintenance, however, are not dependent on axon-derived neuregulin-1 signaling in adulthood.
\end{abstract}

\section{Introduction}

Neuregulins (NRGs) are structurally related glycoproteins, and four genes have been identified encoding NRGs, Nrg1, Nrg2, Nrg3, and Nrg4 (Holmes et al., 1992; Peles et al., 1992; Wen et al., 1992; Falls et al., 1993; Goodearl et al., 1993; Marchionni et al., 1993; Carraway et al., 1997; Zhang et al., 1997; Harari et al., 1999). NRG1 is the most widely studied of the NRGs and is known to have a major role in neural, mammary, and cardiac development (Wen et al., 1994; Nave and Salzer, 2006). Alternative splicing and differential promoter usage gives rise to at least 15 different NRG1 isoforms that demonstrate different spatiotemporal patterns of expression (Meyer et al., 1997; Falls, 2003). All isoforms possess an epidermal growth factor (EGF)-like signaling domain that is essential for mediating biological activity and can be classified into subgroups according to the structure of their $\mathrm{N}$ ter-

Received Dec. 19, 2008; revised May 5, 2009; accepted May 11, 2009.

This work was supported by the Medical Research Council (J.N.W.) and the German Science Foundation (SFB 665) (A.N.G., C.B.).F.R.F. is a Biotechnology and Biological Sciences Research Council Collaborative Awards in Science and Engineering PhD student in part funded by Acorda Therapeutics, Inc. D.L.H.B. is a Wellcome Intermediate Clinical Scientist (Grant 077074/z/05/z). C.T. and M.T. are PhD students of the Wellcome Trust-funded London Pain Consortium. We thank Drs. S. Hall and B. Murinson for advice on the analysis of peripheral nerve anatomy.

Correspondence should be addressed to Dr. David L. H. Bennett, Wolfson Centre for Age-Related Diseases, King's College London, Guy's Campus, London SE1 1UL, UK. E-mail: david.bennett@kcl.ac.uk.

D0I:10.1523/JNEUROSCI.6053-08.2009

Copyright $\odot 2009$ Society for Neuroscience $\quad$ 0270-6474/09/297667-12\$15.00/0 mini. Type I and II isoforms have Ig-like domains and after proteolytic cleavage can be released as soluble proteins from the cell surface. Type III isoforms possess a CRD (cysteine-rich domain) and have two transmembrane domains. This isoform undergoes proteolytic cleavage by BACE1, a process required for some aspects of its biological activity (Hu et al., 2006; Willem et al., 2006).

During development, axonally derived NRG1 binds to erbB2 and erbB3 receptors expressed on Schwann cells (and their precursors); this signaling pathway is critical for the survival of glia and peripheral neurons, Schwann cell proliferation, motility, and finally myelination (Garratt et al., 2000b). The ensheathment fate of the axon depends on a threshold level of NRG1 type III being expressed on the axonal surface (Taveggia et al., 2005). Furthermore, myelin thickness depends on the amount of NRG1 type III expressed on the axolemma (Michailov et al., 2004). Increasing the levels of NRG1 type III produces thicker myelin sheaths, whereas haploinsufficiency of NRG1 type III (Taveggia et al., 2005) or targeted ablation of the erbB2 receptor in myelinating Schwann cells results in thinner myelin sheaths (Garratt et al., 2000a).

NRG-erbB signaling is not only required for establishing the normal interaction of large-diameter axons with myelinating Schwann cells but may have a role in signaling between unmyelinated axons and nonmyelinating Schwann cells (NMSCs), the cell types that form the Remak bundle. A dominant-negative 
erbB4 receptor has been used to disrupt erbB2/3 signaling in NMSCs, resulting in reduced numbers of axons per Remak bundle as well as Schwann cell death and sensory axon loss (Chen et al., 2003).

One difficulty in studying NRG1 function in postnatal development and adulthood has been that the ablation of all NRG1 isoforms results in embryonic lethality because of defective cardiogenesis. Blockade of neuregulin-erbB-mediated axoglial signaling throughout the peripheral nervous system results in perinatal mortality because of respiratory failure (Meyer et al., 1997; Morris et al., 1999; Woldeyesus et al., 1999; Wolpowitz et al., 2000; Falls, 2003). We therefore crossed animals in which Cre is expressed under control elements of the Nav1.8 gene (Nav1.8Cre) with animals in which exons 7-9 of the Neuregulin gene (Nrg1) have been floxed $\left(N r g 1^{f / f}\right)$. This approach results in Nrg1 gene deletion in the majority of small DRG cells (which normally have unmyelinated axons) and a population of large-diameter DRG cells (which normally have thinly myelinated axons), enabling us to study NRG1 function in axoglial signaling between sensory axons and both myelinating and NMSCs.

\section{Materials and Methods}

\section{Animals}

All work performed conformed to United Kingdom Home Office legislation (Scientific Procedures Act 1986). All behavior, surgery, immunohistochemistry, and electron microscopy was performed on animals or tissue taken from 10-week-old animals unless stated otherwise.

The generation and genotyping of mutant mice with floxed alleles of Nrgl $\left(\mathrm{Nrgl}^{f / f}\right)$ and Nav1.8-Cre mice have been described previously (Meyer and Birchmeier, 1995; Yang et al., 2001; Stirling et al., 2005; Brinkmann et al., 2008). In Nav1.8-Cre mice, the onset of Cre expression is at embryonic day 13 (E13), and it is expressed selectively in nociceptors constituting the majority of sensory neurons with unmyelinated axons (C-fibers) and a small group with thin myelinated axons (A $\delta$-fibers) (Stirling et al., 2005; Abrahamsen et al., 2008). Nav1.8-Cre mice have previously been thoroughly characterized. The Nav1.8 sodium channel contributes to the tetrodotoxin-resistant (TTX-r) sodium current, and although these animals are haplotype insufficent for Nav1.8 DRG cells demonstrate a normal TTX-r current density and normal nociceptive behavior (Stirling et al., 2005). Both colonies were on a C57BL/6 background. $\mathrm{Nrg}^{\mathrm{f} / \mathrm{f}}$ mice have loxP sites flanking the essential EGF domain (Li et al., 2002; Brinkmann et al., 2008). Floxed alleles are genetically null for $\alpha$-NRG1 isoforms but have normal peripheral nerve development and can be considered controls. $\mathrm{Nrg}^{f / f}$ and $\mathrm{Nrg}^{f / f} ; \mathrm{Nav1.8-Cre}$ mice were born in expected ratios. In each experiment, $\mathrm{Nrg}^{\mathrm{fff}}$; $\mathrm{Nav1.8-Cre} \mathrm{animals}$ were compared with $\mathrm{Nrg} 1^{\mathrm{f} / f}$ littermate controls. We included equal numbers of animals of each gender in experimental groups where possible.

Cre-mediated recombination in DRG cells was assessed using PCR of genomic DNA; the primers used to detect the presence of the first loxP site

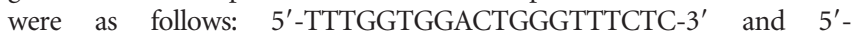
CTGACTGGCCTTTCTTCCAG-3'. The primers used to detect the recombined allele were as follows: $5^{\prime}$-TTTGGTGGACTGGGTTTCTC- 3 ' and $5^{\prime}$ TCACTATGTAGCTCTGGCTGGCATC-3' (both reactions were performed as follows: heating at $94^{\circ} \mathrm{C}$ for $2 \mathrm{~min}, 34$ cycles of $94^{\circ} \mathrm{C}$ for $30 \mathrm{~s}$ $60^{\circ} \mathrm{C}$ for $30 \mathrm{~s}$ and $72^{\circ} \mathrm{C}$ for $50 \mathrm{~s}$, followed by a final extension at $72^{\circ} \mathrm{C}$ for 8 $\mathrm{min})$. For genotyping, ear-derived DNA was analyzed by PCR to identify $\mathrm{Nrg}^{\mathrm{fff}}$;Nav1.8-Cre experimental mice. Primers used to identify the Nav1.8Cre allele were as follows: $5^{\prime}$-TGTAGATGGACTGCAGAGGATGGA-3' and 5'-AAATGTTGCTGGATAGTTTTTACTGCC-3' ( $94^{\circ} \mathrm{C}$ for $3 \mathrm{~min}, 30$ cycles of $94^{\circ} \mathrm{C}$ for $30 \mathrm{~s}, 62^{\circ} \mathrm{C}$ for $30 \mathrm{~s} 72^{\circ} \mathrm{C}$ for $1 \mathrm{~min}$, followed by a final extension at $72^{\circ} \mathrm{C}$ for $10 \mathrm{~min}$ ).

In situ hybridization combined with fluorescence histochemistry All solutions and materials used in tissue preparation and processing for in situ hybridization were RNase-free or DEPC-treated. Histochemistry was performed before in situ hybridization. After a series of washes in DEPC-treated PBS, samples were incubated overnight at room temper- ature with rabbit anti-calcitonin gene-related peptide (CGRP) (1:2000; Sigma-Aldrich) and biotin-conjugated IB4 (1:50; Sigma-Aldrich). After incubation, samples were washed and incubated with donkey anti-rabbit IgG-conjugated Alexa Fluor 546 (1:1000; Invitrogen) and extravidinAMCA (7-amino-4-methylcoumarin-3-acetic acid) (1:400; Vector Laboratories) for $3 \mathrm{~h}$. All antibody dilutions were in DEPC-PBS containing $0.2 \%$ Triton X-100, 0.1\% sodium azide, and $100 \mathrm{U} / \mathrm{ml}$ RNasin Plus ribonuclease inhibitor (Promega). Finally, samples were washed in DEPCtreated PBS.

Prehybridization treatment included acetylation in $0.25 \mathrm{M}$ acetic anhydride/0.1 m triethanolamine, dehydration in graded alcohol $(70-100 \%$ ethanols), and delipidation in $100 \%$ chloroform. In situ hybridization was performed using 34-nt-long radioactive probes as described previously. Oligonucleotides were designed using NetPrimer software, subjected to BLAST analysis to ensure specificity of hybridization (http:// www.ncbi.nlm.nih.gov/blast/Blast.cgi), synthesized (Sigma-Aldrich), and radioactively end-labeled with ${ }^{35}$ S-dATP (PerkinElmer Life and Analytical Sciences) using terminal deoxynucleotidyl transferase (Promega). The NRG1 probe sequence was CTGGTGATCGTTGCCAAAACTACGTAATGGCCAGC, designed to detect the $\beta$ EGF domain of mouse NRG1 mRNA (accession number NM_178591). Hybridization with the oligonucleotide probe was performed overnight at $37^{\circ} \mathrm{C}$. After hybridization, sections were washed in standard saline citrate solutions with increasing stringencies. Slides were dehydrated rapidly through graded alcohols, air-dried, dipped in autoradiographic emulsion (LM1; GE Healthcare), and exposed for 3-4 weeks before development. Slides were either counterstained with toluidine blue and coverslipped with DPX, or mounted with Vectashield (Vector Laboratories) when fluorescence was present. Controls included competition of specific labeling by addition of a 20-fold excess of unlabeled oligonucleotide in the hybridization reaction, as well as identical labeling patterns when using different probes.

\section{DRG cell culture}

Neuronal dissociated DRG cultures were prepared as previously described (Golding et al., 1999). Postnatal day 3 (P3) mice were killed according to institutional (King's College London) and United Kingdom Home Office regulations. The DRGs were dissected, trimmed, and placed in $\mathrm{Ca}^{2+}$ - and $\mathrm{Mg}^{2+}$-free HBSS (Invitrogen). DRGs were then incubated in $0.125 \%$ collagenase (Sigma-Aldrich) at $37^{\circ} \mathrm{C}$ in Ham's F12 medium for $40 \mathrm{~min}$ followed by $0.25 \%$ trypsin/EDTA (Sigma-Aldrich) for $15 \mathrm{~min}$, washed in Ham's F12 containing 10\% fetal calf serum (Sigma-Aldrich), and tritrurated with a P1000 Gilson pipette in $500 \mu \mathrm{l}$ of modified Bottenstein and Sato's culture medium (BS) in Ham's F12. The cell suspension was then centrifuged at $600 \times g$ for $8 \mathrm{~min}$ through a cushion of $15 \%$ BSA (Sigma-Aldrich) to remove myelin debris. Dissociated neurons were resuspended in Bottenstein and Sato's medium containing $50 \mathrm{ng} / \mathrm{ml}$ NGF (Alomone) and 2\% FCS and plated onto coverslips coated with poly-L-lysine (10 $\mu \mathrm{g} / \mathrm{ml}$; Sigma-Aldrich) and laminin (10 $\mu \mathrm{g} / \mathrm{ml}$; SigmaAldrich). Medium was changed daily, and on alternate days $20 \mu \mathrm{M}$ FUDR (fluorodeoxyuridine) (Sigma-Aldrich) was added to reduce the growth of non-neuronal cells.

\section{Western blotting}

Cells from DRG culture were washed with PBS, scraped off the coverslip, lysed, and centrifuged at 12,000 rpm for $15 \mathrm{~min}$. The supernatant was used to determine the protein concentration using the BCA protein assay kit (Pierce; 23227). A total of $50 \mu \mathrm{g}$ of protein was mixed with SDS gel sample buffer and electrophoresed on $8 \%$ SDS-polyacrylamide gels, transferred onto nitrocellulose membrane, blocked in $10 \%$ milk, and immunoblotted with antibodies against NRG1 [Neuregulin- $1 \alpha / \beta 1 / 2(\mathrm{C}$ 20); Santa Cruz; SC-348] at a dilution of 1:500 and $\beta$-III-tubulin (Promega; G7121) at a dilution of 1:2000. Secondary antibodies were antirabbit IgG horseradish peroxidase linked (GE Healthcare; NA9340V) and anti-mouse IgG horseradish peroxidase linked (GE Healthcare; NA931V). ECL plus Western blotting detection system (GE Healthcare) was used to visualize the immunoreactive band on chemiluminescence film (GE Healthcare), which was developed on a Fuji x-ray imager (Mediphot 937). 
A

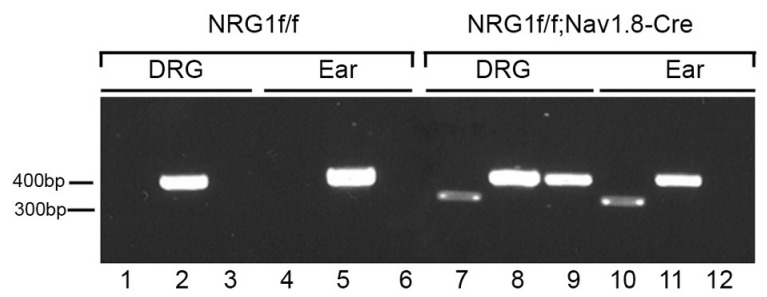

B
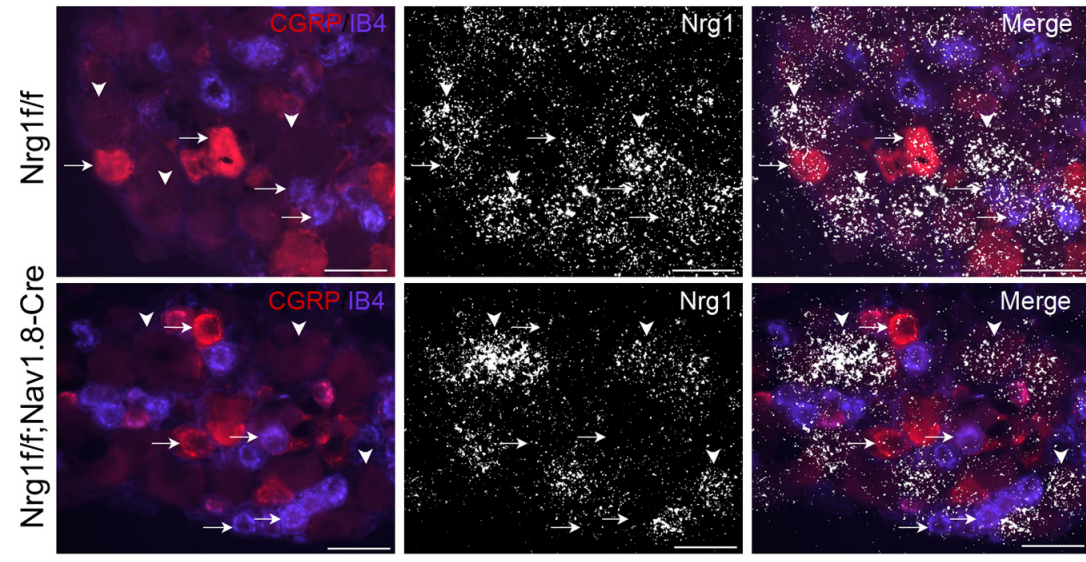

C
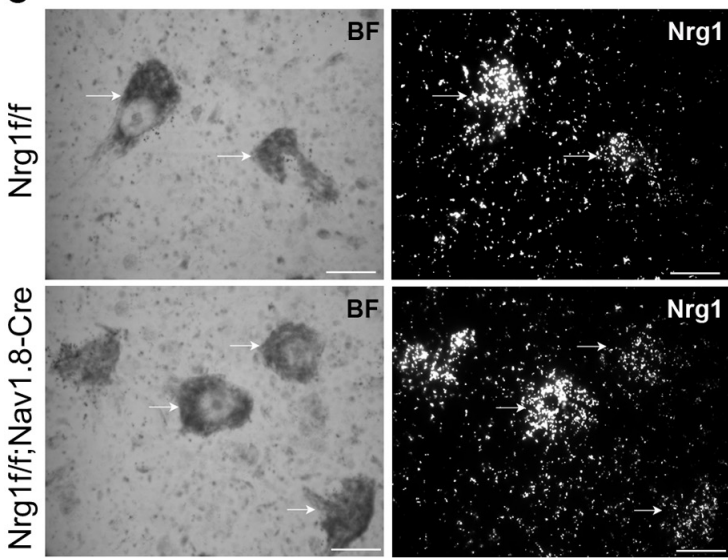

D

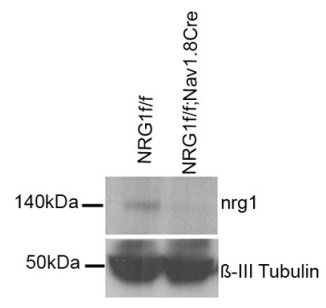

Figure 1. The floxed $\mathrm{Nrg} 1$ locus is efficiently recombined by the Cre recombinase in DRG cells. $A, P C R$ performed on genomic DNA using primers to detect the presence of (re with a product of $\sim 320$ bp in length (lanes $1,4,7$, and 10 ), the loxP site upstream of $\mathrm{Nrg} 1$ exon 7 (lanes 2, 5, 8, and 11), and the recombined $\mathrm{Nrg} 1$ allele (lanes 3, 6, 9, and 12). In an Nrg $7^{\mathrm{ff} f}$ animal, Cre is not present in genomic DNA extracted from DRG and ear (lanes 1 and 4, respectively), and no recombination is observed in either tissue (lanes 3 and 6). In Nrg $7^{f / f} ; \mathrm{Nav1.8}$-Cre, the presence of (re in genomic DNA is confirmed (lanes 7 and $10 \mathrm{in} \mathrm{DRG} \mathrm{and} \mathrm{ear,} \mathrm{respectively),} \mathrm{and}$ a recombination product is seen in the DRG (lane 9 ) but not ear (lane 12). Please note that the unrecombined allele ( $\sim 2200$ bp in length) is too large to be effectively amplified in this PCR. $\boldsymbol{B}$, In situ hybridization images using a probe directed against the EGF domain of NRG1 in L4 DRG of $\mathrm{Nrg}^{\mathrm{f} / \mathrm{f}}$ mice and $\mathrm{Nrg}^{\mathrm{ff} / \mathrm{f}}$;Nav1.8-Cre mice. The arrowheads label examples of large DRG cells, and the arrows label examples of small DRG cells positive for either IB4 (blue) or CGRP (red). In Nrg $7^{\mathrm{f} / \mathrm{f}} ; \mathrm{Nav1.8-Cre} \mathrm{mice,} \mathrm{expression} \mathrm{of} \mathrm{NRG1}$ by large-diameter DRG cells was maintained; however, many small DRG cells can be seen that are negative for NRG1. Pictures were taken at $50 \times$ magnification. Scale bars, $50 \mu \mathrm{m}$. C, In situ hybridization images using the same probe in the lumbar spinal cord of $\mathrm{Nrg}{ }^{f / f}$ mice and $\mathrm{Nrg}^{\mathrm{f} / \mathrm{f}} ; \mathrm{Nav1.8}$-Cre mice. The arrows label motor neurons, all of which are positive for $\mathrm{Nrg} 1$ in both genotypes. Pictures were taken at $100 \times$ magnification. Scale bars, $20 \mu \mathrm{m}$. D, Western blot analysis of postnatal day 3 DRG culture lysates from $\mathrm{Nrg}^{\mathrm{fff}}$ mice and $\mathrm{Nrg} \mathrm{T}^{f / f} ; \mathrm{Nav1.8-Cre} \mathrm{mice.} \mathrm{The} \mathrm{membrane} \mathrm{was} \mathrm{probed} \mathrm{with} \mathrm{a} \mathrm{NRG1} \mathrm{antibody} \mathrm{that} \mathrm{recognizes} \mathrm{the} \mathrm{"a-tail"}$ C-terminal epitope. The $140 \mathrm{kDa}$ band represents full-length NRG1 type III pro-protein and is markedly reduced in $\mathrm{Nrg} \mathrm{1}^{\mathrm{f} / \mathrm{f}} ; \mathrm{Nav1.8-}$ Cre mice. $\beta$-III-Tubulin was used as a loading control.

\section{Histology}

Immunofluorescence microscopy. Animals were deeply anesthetized with pentobarbitone and transcardially perfused with $5 \mathrm{ml}$ of saline followed by $25 \mathrm{ml}$ of paraformaldehyde ( $4 \%$ in $0.1 \mathrm{M}$ phosphate buffer).
Skin biopsies were taken from the hindpaw glabrous skin proximal to the pad below the first digit. Skin, L4 DRG, sciatic and sural nerve tissue were postfixed in paraformaldehyde ( $4 \%$ in $0.1 \mathrm{M}$ phosphate buffer) for $2 \mathrm{~h}$, and then transferred to $20 \%$ sucrose overnight $\left(4^{\circ} \mathrm{C}\right)$. Tissue was then blocked in OCT embedding compound on dry ice and stored at $-80^{\circ} \mathrm{C}$. Transverse sections of skin were cut at $14 \mu \mathrm{m}$ on a cryostat onto chrome alum gelatincovered slides. DRG sections were cut at $10 \mu \mathrm{m}$ and longitudinal nerve sections at $5 \mu \mathrm{m}$ on a cryostat onto SuperFrost Ultra Plus slides. E14.5 and E16.5 embryos were obtained by mating and observing a vaginal plug; the day of the vaginal plug was defined as embryonic day 0.5 . Embryos were postfixed in paraformaldehyde ( $4 \%$ in $0.1 \mathrm{~m}$ phosphate buffer) overnight and transferred sequentially to 10,20 , and $30 \%$ sucrose for $1 \mathrm{~d}$ at each concentration $\left(4^{\circ} \mathrm{C}\right)$ before being embedded in OCT compound on dry ice and stored at $-80^{\circ} \mathrm{C}$. Twenty-micrometerthick sections of whole embryos were cut transversely.

C-fibers in the epidermis were visualized by immunostaining with the pan-neuronal marker protein gene product (PGP), polyclonal rabbit PGP9.5 (Ultraclone; 1:800; $14 \mathrm{~h}$ ) or polyclonal sheep CGRP (BIOMOL; CA1137; 1:800; 14 h). Secondary antibodies used were anti-rabbit $\mathrm{Cy} 3$ (Stratech; 711-166-152; 1:500; $2.5 \mathrm{~h}$ ) and antisheep Cy3 (Stratech; 713-166-147; 1:400; 2.5 h), respectively. DRG cell profiles were visualized by staining for either IB4 Isolectin $\mathrm{B}_{4}$ biotin conjugate $\left(B S I-B_{4} ; 10 \mu \mathrm{g} / \mathrm{ml}\right.$; Sigma-Aldrich; L2140; $14 \mathrm{~h})$, CGRP (1:800; $14 \mathrm{~h}$ ), or monoclonal mouse anti-neurofilament 200 clone N52 [NF200 (N52); 1:500; Sigma-Aldrich; N0142; 14 h], all of which were double stained with PGP9.5 to aid counting the total number of profiles. Secondary antibodies used were as follows: ExtrAvidin-FITC (SigmaAldrich; E 2761; 1:500; 2.5 h) with anti-rabbit Cy3 for IB4 double staining; anti-sheep Cy3 with goat anti-rabbit FITC (Stratech; 111-096-003; 1:200; $2.5 \mathrm{~h}$ ) for CGRP double staining; donkey antimouse FITC (Stratech; 715-095-150; 1:200; 2.5 h) with anti-rabbit Cy3 for NF200 (N52) double staining. Incubation of primary antibodies was overnight and was preceded by an incubation with normal donkey serum (Millipore Bioscience Research Reagents; S30; 1:10; $30 \mathrm{~min})$. All reagents were diluted in PBS/0.2\% Triton X-100/ $0.1 \%$ sodium azide.

Immunofluorescence was visualized under a Zeiss Imager.Z1 microscope. Epidermal fibers were counted at a $40 \times$ magnification live on the microscope according to rules set out by Lauria et al. (2005). Only nerve fibers that can be seen to cross the basement membrane were counted. If the nerve fiber diverged into two fibers before crossing the membrane, it was counted as two fibers, whereas if the fiber diverged after crossing the membrane it was counted as only one fiber. Nerve fragments in the epidermis that did not cross the basement membrane in the section were not counted. Skin sections were numbered and then selected randomly using randomly generated numbers. Four sections per animal were counted blind, twice. Photographs were taken using the Axio Cam at $10 \times$ magnification in a mosaic. The length 
of the epidermis was measured using Image J and used to calculate intraepidermal nerve fiber density (IENFD) (number of fibers per millimeter). Photographs of DRG sections were taken using the Axio Cam at $40 \times$ magnification in a mosaic. Two sections per animal per staining were counted blind from a photograph taken using AxioVision LE, release 4.2, software. Positive cell profiles were counted as well as negative to get a percentage of total cell profiles for each marker. The same software was used to measure the diameter of DRG profiles for cell size distributions.

Terminal deoxynucleotidyl transferasemediated biotinylated UTP nick end labeling (TUNEL) analysis staining was performed using an ApopTag Fluorescein In Situ Apoptosis Detection kit (Millipore Bioscience Research Reagents; S7110) according to the manufacturer's instructions. Nerve sections were counterstained with 4',6'-diamidino-2-phenylindole (DAPI) mounting medium (Vector Laboratories; $\mathrm{H}-1200$ ) to identify nuclei for total counts. Photographs of all of the fields covering the whole of each longitudinal nerve section were taken at $40 \times$ magnification. The number of fields varied depending on the nerve and the age of the animal; at least two nerve sections were analyzed per animal. More than 1000 cells were counted blind per genotype at each time point, and TUNEL-positive cells were represented as a percentage of total cell number. TUNELpositive embryonic DRG cells were counted blind in at least six L4/5 DRG sections per animal.

Electron microscopy. Animals were deeply anesthetized with pentobarbitone and transcardially perfused with $5 \mathrm{ml}$ of saline followed by $25 \mathrm{ml}$ of $4 \%$ paraformaldehyde, $3 \%$ glutaraldehyde in $0.1 \mathrm{M}$ phosphate buffer. Sural nerves were dissected and a $5 \mathrm{~mm}$ length taken as it reaches the gastrocnemius muscle. Nerves were postfixed in $3 \%$ glutaraldehyde at $4^{\circ} \mathrm{C}$ overnight, washed in $0.1 \mathrm{M} \mathrm{PB}$, osmicated, dehydrated, and embedded in epoxy resin (TAAB Embedding Materials). Sections $1 \mu \mathrm{m}$ thick were cut on a microtome and stained with toluidine blue before being examined on a light microscope. Ultrathin sections were cut on an ultramicrotome and stained with lead uranyl acetate by the Centre for Ultrastructural Imaging (King's College London). Sections were mounted on unsupported 100 mesh grids, and uninhibited sections were visualized on a Hitachi H7600 transmission electron microscope.

For analysis, photographs of the entire section of one nerve from each animal were taken at a magnification of $15,000 \times$. Total counts of myelinated and unmyelinated axons as well as Schwann cell nuclei were performed of the whole cross section of the nerve. The $g$ ratios of 100 axons and C-fiber diameters of 300 axons, chosen using randomly generated numbers, were measured per animal using AxioVision LE, release 4.2, software.

\section{Neurophysiology}

The conduction velocity (CV) of individual A- and C-fibers projecting through the sciatic nerve was measured in urethane-anesthetized animals (terminal urethane anesthesia; $1.25 \mathrm{~g} / \mathrm{kg}$, i.p.). A tracheal cannula was in-

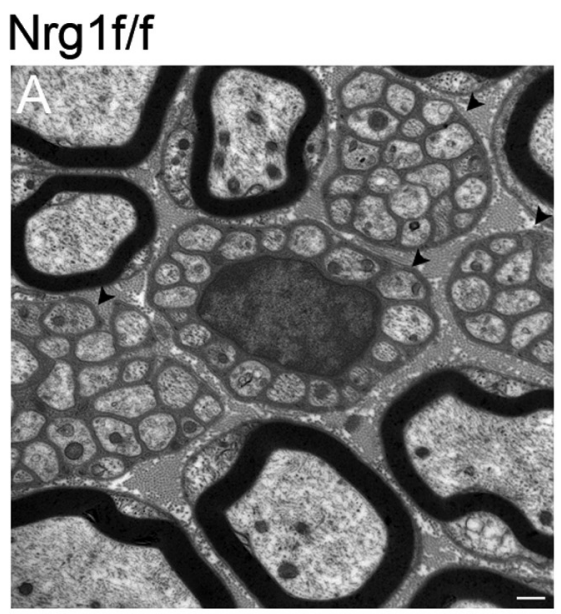

Nrg1f/f;Nav1.8-Cre
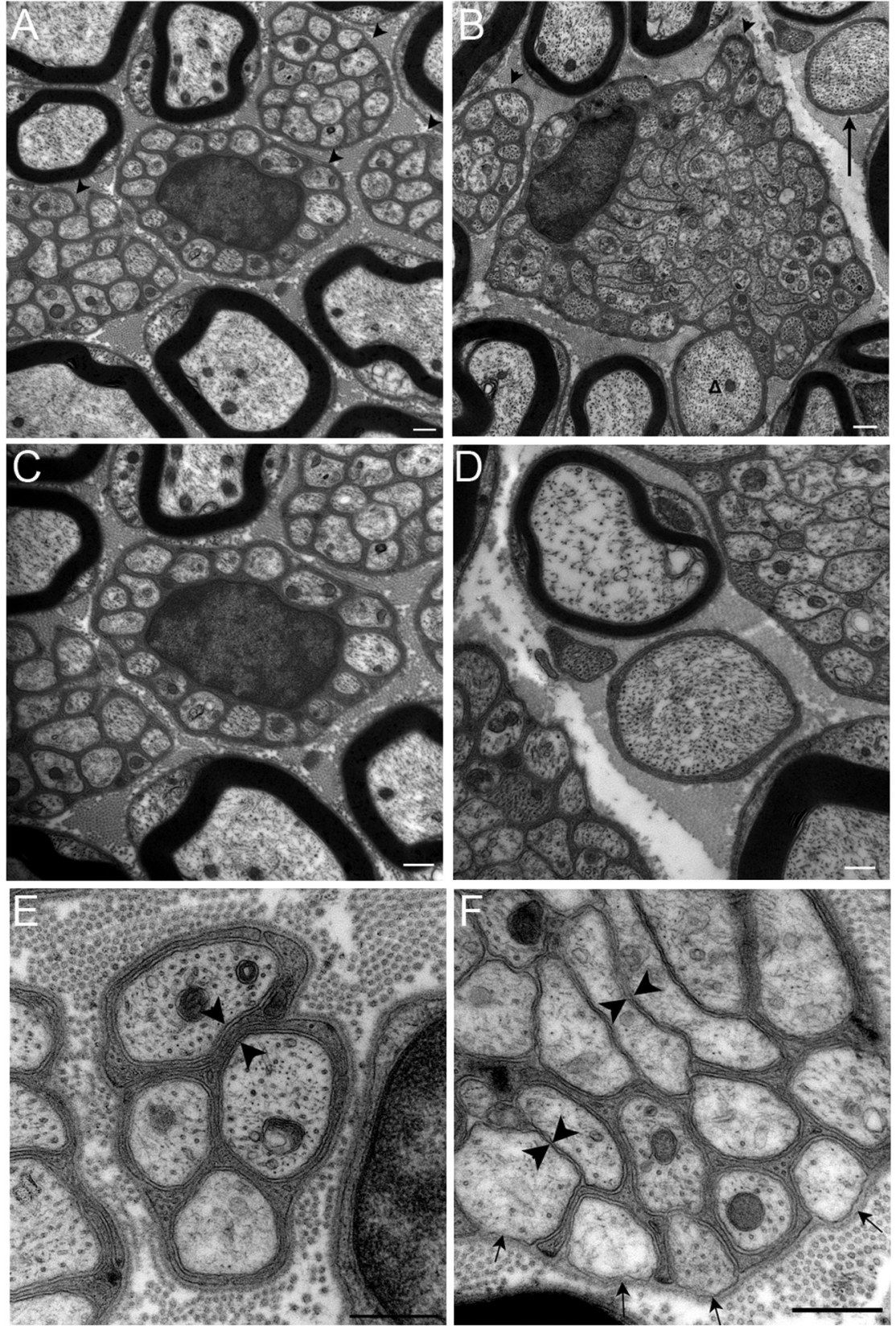

Figure 2. NRG1 is necessary for normal Remak bundle structure and myelination. $A-F$, Electron micrographs of transverse

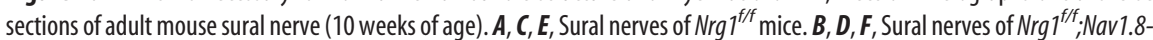
Cre mice. Magnification: $A, B, 15,000 \times ; C, D, 25,000 \times ; E, F, 60,000 \times . A-D$, Note the difference in Remak bundles (arrowheads) between the $\mathrm{Nrg}{ }^{f / f}$ mice $(A, C)$ in which each unmyelinated axon is separated by $S$ chwann cell cytoplasm and are of similar sizes, and the $\mathrm{Nrg}^{\mathrm{fff}}$; Nav1.8-Cre mice $(\boldsymbol{B}, \boldsymbol{D})$ in which Remak bundles are greatly enlarged. $\Delta$ labels an abnormally large fiber still within the Remak bundle. A large fiber of diameter of $1.976 \mu \mathrm{m}$, which would usually be myelinated (arrow), is completely amyelinated; at high magnification $(\boldsymbol{D})$, it is clearly invested in Schwann cell cytoplasm and a basement membrane can be seen to surround the fiber. The separation of unmyelinated axons by Schwann cell cytoplasm can be seen clearly at high magnification $(\boldsymbol{C}-\boldsymbol{F})$; arrowheads highlight the distance between unmyelinated fibers. $\boldsymbol{F}$, Note in $\mathrm{Nrg}^{\mathrm{ff}}$; Nav1.8-Cre mice many axons are not separated by Schwann cell cytoplasm; note also the type II axon/Schwann cell relationship in which the mesaxon is breached and the axon is directly exposed to the endoneurium (arrows). Scale bars, $500 \mathrm{~nm}$. 
Table 1. Quantification of sural nerve morphometry using electron microscopy

\begin{tabular}{lcc}
\hline & $N^{\prime} g 1^{f / f}$ & Nrgl $^{f / f} ;$ Nav1.8-Cre \\
\hline Total fibers & $3452.5 \pm 100.19$ & $3581.25 \pm 197.01$ \\
\% Myelinated fibers & $19.92 \pm 0.52$ & $16.44 \pm 0.28^{* *}$ \\
\% Unmyelinated fibers & $80.08 \pm 0.52$ & $83.56 \pm 0.28^{* *}$ \\
No. myelinating Schwann cell nuclei & $21.25 \pm 2.17$ & $17.5 \pm 1.5$ \\
No. nonmyelinating Schwann cell nuclei & $11.75 \pm 0.75$ & $12.25 \pm 1.11$ \\
Total no. Schwann cell nuclei & $33 \pm 1.78$ & $29.75 \pm 2.5$ \\
No. of Remak bundles & $260.5 \pm 15.39$ & $221.5 \pm 13.76$ \\
C-Fibers per Remak bundle & $10.73 \pm 0.75$ & $13.54 \pm 0.4^{*}$ \\
No. bundles with polyaxonal pockets & $23 \pm 2.42$ & $74.25 \pm 7.34^{* * *}$ \\
\% Bundles with polyaxonal pockets & $9.06 \pm 1.42$ & $34.2 \pm 4.81^{* *}$ \\
Average $g$ ratio & $0.687 \pm 0.003$ & $0.718 \pm 0.003^{* * *}$ \\
Unmyelinated fiber diameter & $0.487 \pm 0.004$ & $0.537 \pm 0.008^{* * *}$ \\
Myelinated fiber diameter & $2.36 \pm 0.04$ & $2.54 \pm 0.04^{* *}$ \\
\hline
\end{tabular}

Quantification of sural nerve morphometry using electron microscopy. Values are shown as \pm SEM.

${ }^{*} p<0.05,{ }^{* *} p<0.01$, and ${ }^{* * *} p<0.001$, respectively, by Student's $t$ test.

possible to evoke activity in sensory axons by applying graded electrical stimuli to the sciatic nerve and recording the individual action potentials as they passed over the recording electrodes. Dividing the distance between these sets of electrodes by the conduction time taken for action potentials yields the conduction velocity of individual axons. Groups of myelinated and unmyelinated axons (typically $30-50$ per animal) were studied. To evoke activity in A-fibers $(\mathrm{CV},>2 \mathrm{~m} / \mathrm{s})$, the sciatic nerve was stimulated using a square wave current pulse of duration $100 \mu \mathrm{S}$. The evoked activity on the root filament was amplified and filtered by conventional means. The stimulating current was gradually increased up to a maximum of $500 \mu \mathrm{A}$, which is sufficient to recruit all A-fibers in the nerve. This procedure typically resulted in a group of 3-10 axons being progressively recruited with increasing current strengths in each strand. To stimulate $\mathrm{C}$-fibers $(\mathrm{CV},<2 \mathrm{~m} / \mathrm{s})$, a square wave current pulse of $1 \mathrm{~mA}$ for $1 \mathrm{~ms}$ was used. When recording activity in C-fibers, 32 responses were averaged (to reveal relatively small potentials). Because of the relative slowness of conduction in these fibers, the action potentials evoked are dispersed by the time they reach the recording electrodes and they generally are not superimposed. It was therefore possible to identify action potentials from individual $\mathrm{C}$ axons in these recordings, from which the latency (and hence conduction velocity) was determined (see Fig. $4 A, B$ ). There were usually 5-10 A and 3-10 C-fibers per strand (and typically $10-15$ strands would be studied, resulting in a total of $\sim 50 \mathrm{~A}$ and 50 $\mathrm{C}$-fibers being collected per animal). Conduction velocity distributions were expressed as cumulative sums (Qsums) and then compared statistically using the Kolmogorov-Smirnov test.

\section{Behavioral tests}

All behavioral testing was performed with the observer blind to the genotype of the animal.

Mechanical withdrawal threshold assessed using von Frey hairs. Static mechanical withdrawal thresholds were assessed by applying von Frey hairs (Somedic) to the plantar surface of the hindpaw. Unrestrained animals were acclimatized in acrylic cubicles $(8 \times 5 \times 10 \mathrm{~cm})$ atop a wire mesh grid for up to $60 \mathrm{~min}$ before testing. Calibrated von Frey hairs were applied to the plantar surface of the hindpaw until the fiber bent. The $50 \%$ withdrawal threshold was determined using the up-down method described previously (Dixon, 1980).

Randall-Selitto test of mechanosensation. Animals were placed in a restrainer and left to settle for a few minutes. Force was applied approximately midway along the tail. The force at which the animal attempted to withdraw the tail, vocalize, or struggle was recorded (Takesue et al., 1969). The test was repeated three times for each animal. Results were expressed as the mean weight tolerated for each group.

Hargreaves test of thermal nociception. Heat-pain threshold of the hindpaw was ascertained with the Hargreaves method using the Plantar Test (7370; active intensity, 20\%; Ugo Basile) (Hargreaves et al., 1988). Unrestrained animals were acclimatized in acrylic cubicles $(8 \times 5 \times 10$ $\mathrm{cm}$ ) atop a uniform glass surface for up to $60 \mathrm{~min}$ before testing. An infrared light source was directed onto the plantar surface of the hindpaw, and the latency to paw withdrawal was measured in seconds. Four responses were recorded for each hindpaw on each testing occasion with at least 2 min between stimuli. To avoid tissue injury, the maximum stimulus latency was $20.0 \mathrm{~s}$.

Hot-plate test. The response to thermal stimuli was tested using a hotplate analgesia meter (Ugo Basile). Mice were acclimatized to the hotplate chamber for $15 \mathrm{~min}$ before the plate was heated. The latency for hindpaw withdrawal at two temperatures, 50 and $55^{\circ} \mathrm{C}$, was measured. The latency was measured once for each animal, and the tests at different temperatures were separated by at least $24 \mathrm{~h}$. A cutoff latency time of 60 and $30 \mathrm{~s}$ for 50 and $55^{\circ} \mathrm{C}$, respectively, was imposed in each measurement to avoid lesions to the skin and unnecessary suffering to the animals.

Cold-plate test. An incremental hot-cold plate analgesia meter (IITC Life Science) was used to assess noxious cold sensitivity on the plantar surface of the paw as previously described (Kwan et al., 2006). Mice were placed on the surface maintained at $0 \pm 0.5^{\circ} \mathrm{C}$, and pain was assessed by counting the number of hindpaw lifts or jumping during a 5 min period. The mean number of the nocifensive responses was determined by counting over two separate trials conducted with at least a $60 \mathrm{~min}$ interval to prevent thermal sensitization and/or behavioral interferences. Results were expressed as the mean nocifensive responses for each group.

Rotarod. Mice were placed on the rotarod (Jones and Roberts, 1968) as it was rotating at $20 \mathrm{rpm}$. After $1 \mathrm{~min}$, the rate of revolution was increased and reached a maximum of $36 \mathrm{rpm}$ within $90 \mathrm{~s}$. The duration that each animal spent on the rod was measured, with a cutoff time of $5 \mathrm{~min}$. The test was performed three times for each animal with an interval of at least $15 \mathrm{~min}$ between each test.

\section{Statistical analysis}

Differences between $\mathrm{Nrgl}^{\mathrm{fff}}$; $\mathrm{Nav1.8}$-Cre animals and $\mathrm{Nrgl}^{\mathrm{f} / \mathrm{f}}$ littermate controls were determined using the Student's $t$ test for a single time point and two-way repeated-measures ANOVA using the Tukey's post hoc test, with genotype and time points as factors. Results are reported as mean values \pm SEM. Conduction velocity cumulative sum plots were compared statistically using the Kolmogorov-Smirnov test, as were cell size, and axon diameter frequency distributions.

\section{Results}

\section{Efficient ablation of NRG1 in sensory neurons}

In this study, we used mice expressing the Cre recombinase transgene under the control of the Nav1.8 promoter (Stirling et al., 2005). When crossed with mice homozygous for the conditional Nrg1 allele $\left(\mathrm{Nrgl}^{\mathrm{f} / f}\right)$, which have loxP sites flanking the essential EGF domain (Meyer and Birchmeier, 1995; Yang et al., 2001), this sequence, which is present in all Nrg1 isoforms, is conditionally ablated in the majority of small-diameter as well as a population of large-diameter DRG cells. Genomic DNA from control $\mathrm{Nrg1}^{\mathrm{f} / \mathrm{f}}$ and knock-out $\mathrm{Nrg}^{\mathrm{f} / f}$; Nav1.8-Cre DRGs show recombination of the allele in the presence of Cre recombinase expression (Fig. 1A). In situ hybridization using a probe directed against the $\beta$ isoform of the EGF domain confirms the specificity of NRG1 ablation at the mRNA level specifically within small-diameter DRG cells (Fig. $1 \mathrm{~B}$, arrows). In Nrg1 f/f animals, the highest level of expression of NRG1 is seen in the large-diameter DRG cells (Fig. $1 B$, arrowheads) as has previously been demonstrated (Bermingham-McDonogh et al., 1997); however, expression is seen at a low level in small-diameter DRG cells identified by the markers CGRP and IB4. Expression of NRG1 in the CGRP and IB4 populations is mostly absent in $\mathrm{Nrg}^{\mathrm{flf}}$; Nav1.8-Cre animals; however, large-diameter DRG cells (which are CGRP and IB4 negative) continue to show a normal pattern of expression. In Nav1.8-Cre animals, Cre is selectively expressed in sensory neurons, and therefore, as expected, the normal expression of NRG1 in motoneurons is observed in $\mathrm{Nrg}^{\mathrm{fff}}$; Nav1.8-Cre animals (Fig. $1 C$, arrows). No signal was seen after addition of a 20 -fold excess of unlabeled oligonucleotide in the hybridization reaction dem- 
onstrating the specificity of the radiolabeled probe (supplemental Fig. 1, available at www.jneurosci.org as supplemental material). Additional evidence of NRG1 ablation in small-diameter sensory neurons was shown at the protein level by Western blotting analysis of protein lysate of postnatal DRG cell cultures that are grown in the presence of NGF (which selects for small-diameter DRG cells) (Fig. 1D). The amount of NRG1 detected in DRG cell cultures from $\mathrm{Nrgl}^{f / f} ; \mathrm{Nav1.8-Cre} \mathrm{mice} \mathrm{is}$ markedly reduced.

\section{Loss of NRG1 in sensory neurons leads to altered Remak bundle structure as well as myelination defects}

The sural nerve was chosen for electron microscopic analysis as it is a cutaneous sensory nerve and consequently is enriched in A- and C-fibers affected by the ablation of $\mathrm{Nrg} 1$ in these animals. $N r g 1^{f / f}$; Nav1.8-Cre animals demonstrated an obvious phenotype in relation to both Remak bundle structure and myelination (Fig. 2). Strikingly large Remak bundles were observed with many more axons present per bundle than in $\mathrm{Nrgl}^{f / f}$ animals. In $\mathrm{Nrgl}^{f / f}$ animals, unmyelinated axons were individually ensheathed by extensions of Schwann cell cytoplasm so that they were separated from each other; however, in contrast, the C-fibers within the Remak bundles of $\mathrm{Nrgl}^{\mathrm{fff}}$;Nav1.8-Cre mice were much more closely packed, and often not separated by Schwann cell cytoplasm, resulting in "polyaxonal" pockets that are normally only rarely seen in peripheral nerve (Murinson and Griffin, 2004) (Fig. $2 \mathrm{E}, \mathrm{F}$, arrowheads). In addition, in $\mathrm{Nrgl}^{\mathrm{f} / \mathrm{f}}$; Nav1.8-Cre mice we observed examples of type II axon/Schwann cell relationship in which the mesaxon is breached and the axon is directly exposed to the endoneurium (Fig. $2 F$, arrows) (Murakawa et al., 2002). There was a much greater range of sizes of C-fibers within the Remak bundles of $\mathrm{Nrg}^{\mathrm{flf}}$; Nav1.8-Cre mice (Fig. $2 \mathrm{~B}$ ).

Electron microscopy was used to count the total number of axons within the sural nerve, which was unchanged in $\mathrm{Nrgl}^{\mathrm{flf}}$; Nav1.8-Cre mice. However, a greater proportion of axons were unmyelinated (Table 1). Interestingly, there was a population of large-diameter fibers in a 1:1 relationship with a Schwann cell, surrounded by a basal lamina but having failed to myelinate (Figs. $2 D, 3 B$ ). The presence of such fibers indicates that amyelination was not solely attributable to impaired ensheathment. A percentage of $30.8 \pm 2.8 \%$ of the amyelinated fibers $>1 \mu \mathrm{m}$ in diameter were in a 1:1 relationship with a Schwann cell, the rest being present in Remak bundles. There was therefore a change at both ends of the frequency distribution when plotting the number of unmyelinated axons per Schwann cell unit (Fig. 3C). The proportion of

A

B
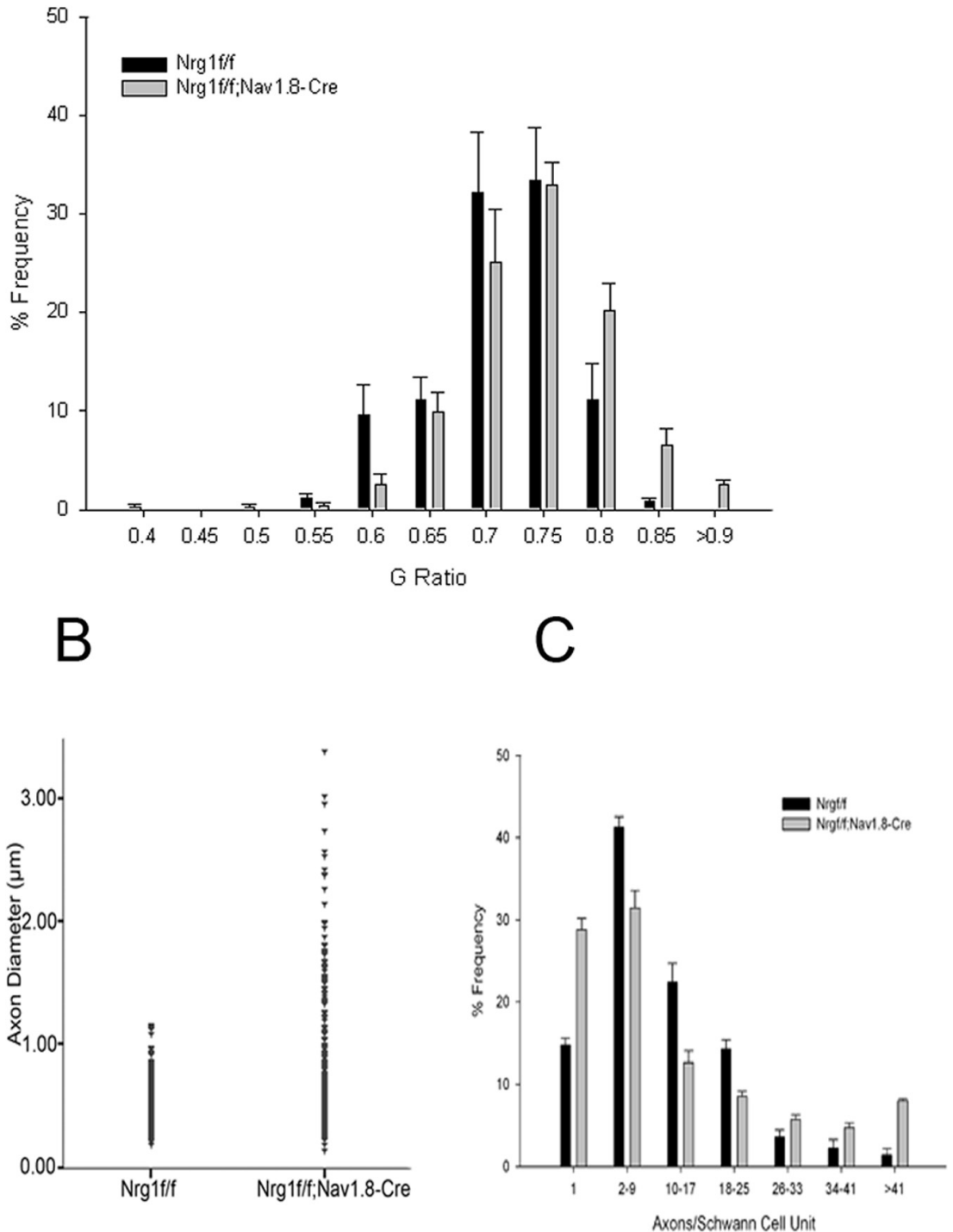

Figure 3. Analysis of effect of NRG1 ablation on myelinated and unmyelinated fiber diameter. Morphometric data calculated from electron micrographs of sural nerves from 10 -week-old mice $(n=4)$. $A$, Frequency distribution of $g$ ratios. Nrg $1^{f / f}$ mice have an average $g$ ratio of $0.68738 \pm 0.00329$ and $N r g 1^{f / f}$; Nav1.8-Cre have an average $g$ ratio of $0.71841 \pm 0.00337$ (Student's $t$ test, $p<0.001$ ). Note the shift to higher $g$ ratios in $\mathrm{Nrg}^{\mathrm{f} / \mathrm{f}}$;Nav1.8-Cre mice (Kolmogorov-Smirnov test, $\left.p<0.001\right)$. B, Quantitative analysis of the axon diameter of unmyelinated fibers. Note that, in $\mathrm{Nrg}^{\mathrm{f} / \mathrm{f}}$; Nav1.8-Cre mice, there is a new population of largediameter axons ( $>1 \mu \mathrm{m}$ diameter) that are unmyelinated compared with the $\mathrm{Nrg}^{\mathrm{f} / \mathrm{f}}$ mice (there was a significant increase in the proportion of unmyelinated axons with a diameter $>1 \mu \mathrm{m} ; \chi^{2}$ analysis, $\left.p<0.001\right)$. C, Frequency distribution showing the number of unmyelinated axons/nonmyelinating Schwann cell. Note that the percentage frequency of unmyelinating axons in a 1:1 ratio doubles in $\mathrm{Nrg}^{\mathrm{f} / \mathrm{f}}$; Nav1.8-Cre mice compared with the $\mathrm{Nrg} 7^{\mathrm{f} / \mathrm{f}}$ mice. This increase is likely to be secondary to those large-diameter axons that are in 1:1 relationship with a Schwann cell but that have failed to myelinate. Nrg ${ }^{\text {f/f }} ; \mathrm{Nav1.8}$-Cre mice also have an increase in the Schwann cell units containing large numbers of axons. These changes lead to a significant change in the frequency distribution (Kolmogorov-Smirnov test, $p<0.001$ ). Error bars indicate SEM.

unmyelinated axons associated with a Schwann cell in a 1:1 ratio increased from $14.7 \pm 0.8 \%$ (mean \pm SEM) in Nrg1 $1^{f / f}$ mice to $28.8 \pm$ $1.3 \%$ in $\mathrm{Nrgl}^{\mathrm{fff}}$;Nav1.8-Cre mice (Fig. 3C) (Sharghi-Namini et al., 2006). As described above, $\mathrm{Nrgl}^{\mathrm{flf}}$; Nav1.8-Cre mice also had a greater proportion of Schwann cell units containing large numbers of unmyelinated axons resulting in a significant change in the frequency distribution (Fig. $3 C)(p<0.001$, Kolmogorov-Smirnov test). We also noted a small population of larger myelinated fibers 
A

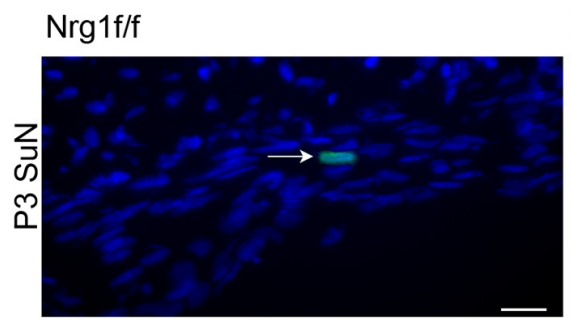

Nrg1f/f;Nav1.8-Cre
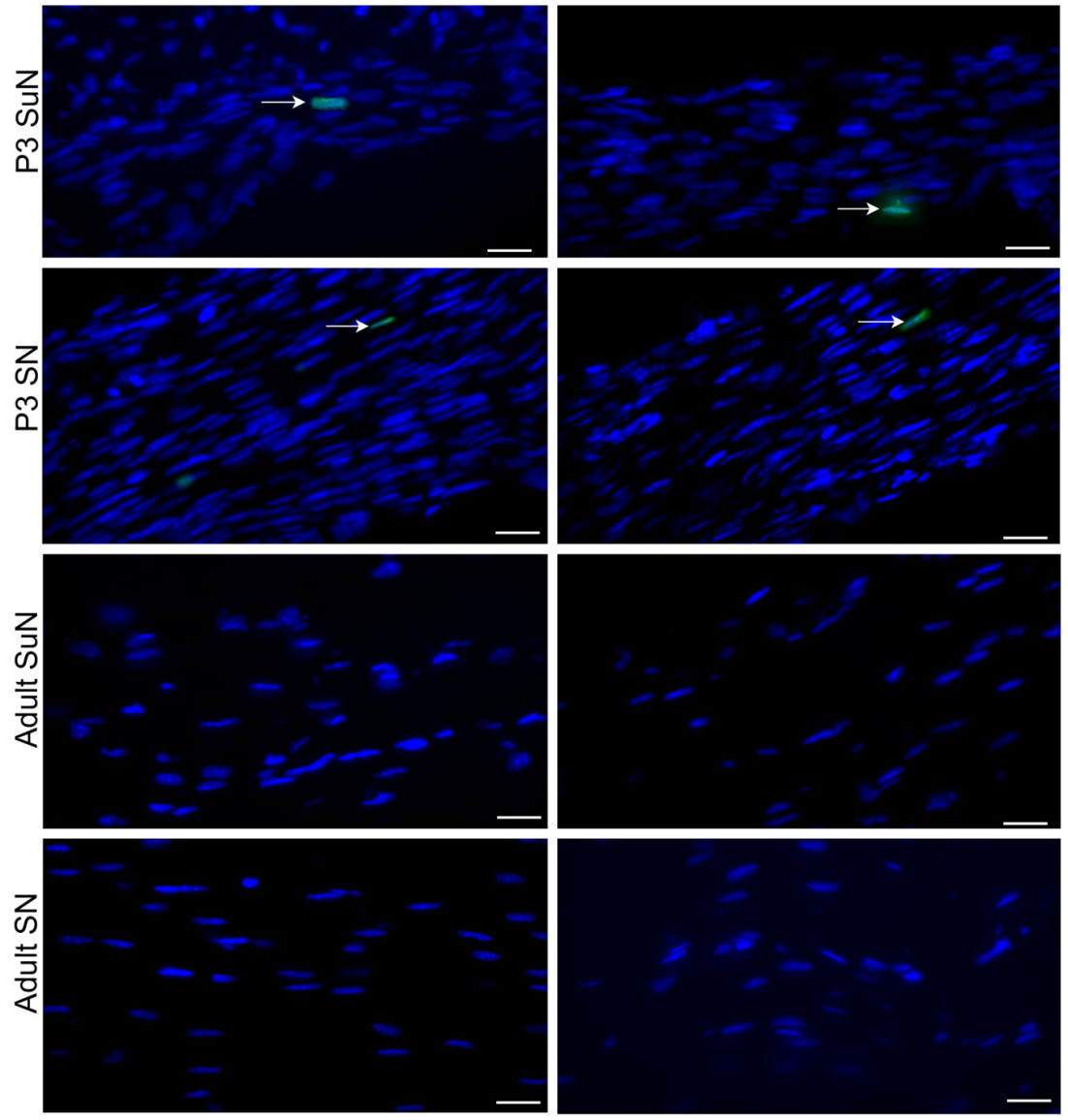

$\mathrm{B}$

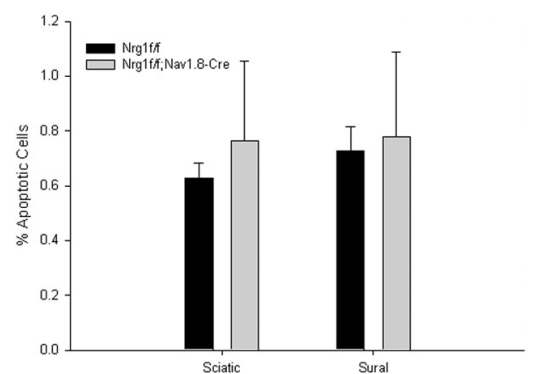

Figure 4. There is no difference in apoptosis of Schwann cells between $\mathrm{Nrg}^{\mathrm{ffff}}$ and $\mathrm{Nrg} \mathrm{f}^{\mathrm{fff}} ; \mathrm{Nav1}$.8-Cre mice. A, Photomicrographs of longitudinal sections of sciatic and sural nerve stained for apoptosis using the TUNEL system and DAPI as a nuclear stain at P3 and adult. No apoptotic nuclei were seen in adult sural or sciatic nerve. B, Quantitative analysis of TUNEL-positive cells at P3 in sciatic and sural nerve. There was no significant difference between $\mathrm{Nrg}^{\mathrm{fff}}$ and $\mathrm{Nrg} \mathrm{7}^{\mathrm{f} / \mathrm{f}} ; \mathrm{Nav1.8}$-Cre mice. Error bars indicate SEM. Images are at $40 \times$ magnification. Scale bars, $20 \mu \mathrm{m}$.

that appear to have proportionately thinner myelin in relation to the axon diameter reflected by an increase in the average $g$ ratio and a significant shift in the frequency distribution (Fig. $3 A)(p<0.001$, Kolmogorov-Smirnov test) (supplemental Fig. 2, available at www.jneurosci.org as supplemental material). The mean axon diameter of both unmyelinated and myelinated axons increased, representing the fact that a population of small-diameter myelinated axons have become large-diameter unmyelinated axons in the $\mathrm{Nrg}^{\mathrm{flf}} ; \mathrm{Nav1.8}$ Cre mice (Table 1).
There was no decrease in the number of Schwann cell nuclei of either myelinating or NMSCs (Table 1), and no apoptotic Schwann cells were seen by electron microscopy. Using TUNEL staining, we examined Schwann cell apoptosis in postnatal (P3) and adult sciatic and sural nerve. As previously described, Schwann cell apoptosis was observed in the postnatal but not adult nerve (Grinspan et al., 1996). There was no significant difference in the proportion of TUNEL-positive Schwann cell nuclei in the $\mathrm{Nrgl}^{\mathrm{f} / \mathrm{f}}$; Nav1.8-Cre compared with $\mathrm{Nrg}^{\mathrm{f} / f}$ animals (Fig. 4). Nav1.8 is not expressed in sympathetic neurons, and therefore, as expected, the appearance of unmyelinated axons in the lumbar sympathetic plexus of $\mathrm{Nrg}^{\mathrm{flf}}$; Nav1.8-Cre animals was normal (supplemental Fig. 3, available at www.jneurosci.org as supplemental material). The anatomical phenotype in peripheral sensory nerves in NRG1 knock-out animals strongly suggests a role of NRG1 in signaling between unmyelinated axons and NMSCs as well as in myelination.

\section{Ablation of NRG1 leads to altered conduction in sensory axons}

The shape of action potentials recorded from primary afferents in the $\mathrm{Nrgl}^{f / f}$; Nav1.8-Cre mice appeared normal, but there were changes in conduction velocity (Fig. 5). The distribution of CVs of individual myelinated fibers (i.e., conducting at $>2 \mathrm{~m} / \mathrm{s}$ ) is shown as cumulative sum plots in Figure $5 C$. There was a significant slowing of $\mathrm{CV}$ in $\mathrm{Nrgl}^{f / f}$; Nav1.8-Cre mice compared with $\mathrm{Nrg} 1^{\mathrm{f} / \mathrm{f}}$ control mice (Fig. 5C) $(p<0.05$, Kolmogorov-Smirnov test), which was apparent for the more slowly conducting A-fibers. This observation is consistent with the known expression of Nav1.8 in some small myelinated axons, and the loss of neuregulin expression form those in the Nrg1 $1^{f / f}$;Nav1.8-Cre mice. There was also a greater electrical threshold for activation in this population of units. Whereas in $\operatorname{Nrg}^{f / f}$ animals only 1 of 208 units recorded with a $\mathrm{CV}>2 \mathrm{~m} / \mathrm{s}$ required stimulation using the $\mathrm{C}$-fiber rather than A-fiber parameters (as described in Materials and Methods), this was the case in 51 of 262 such units recorded in $\mathrm{Nrgl}^{f / f}$; Nav1.8Cre mice ( $p<10^{-5}, \chi^{2}$ test). The CV slowing and increased thresholds seen in the $\mathrm{Nrgl}^{\mathrm{flf}}$;Nav1.8-Cre mice is likely to represent the electrophysiological consequences of failure/impairment of myelination of a population of large-diameter axons corresponding to our findings on morphometric analysis. Fibers conducting $>12 \mathrm{~m} / \mathrm{s}$ have a virtually identical CV distribution when comparing $\mathrm{Nrg}^{f / f}$;Nav1.8-Cre and $\mathrm{Nrgl}^{\mathrm{f} / f}$ mice. 
A cumulative sum plot of fibers recorded with a $\mathrm{CV}$ of $<2 \mathrm{~m} / \mathrm{s}$ (i.e., C-fiber conduction range) is shown in Figure $5 D$. There was a significant increase in $\mathrm{CV}$ in $\mathrm{Nrgl}^{f / f}$;Nav1.8-Cre mice compared with control $N r g 1^{f / f}$ mice particularly in the range of $1-2 \mathrm{~m} / \mathrm{s}(p<0.05$, KolmogorovSmirnov test). This is likely to represent a population of large-diameter axons (which would normally be $\mathrm{A} \delta$-fibers) that have failed to myelinate and therefore now conduct in the $\mathrm{C}$-fiber range. There was no difference in $\mathrm{CV}$ distribution in the slower part of the range $(0-0.8 \mathrm{~m} / \mathrm{s})$ and in particular no slowing of CV in $\mathrm{Nrg}^{\mathrm{flf}}$; $\mathrm{Nav1.8-}$ Cre animals.

\section{Epidermal innervation and DRG cell histochemistry are unaltered after NRG1 ablation}

We investigated whether NRG1 ablation led to increased DRG cell apoptosis during development. Naturally occurring DRG cell death occurs between E12.5 and E16 in the mouse (White et al., 1998). The TUNEL-positive DRG cell profile counts were unchanged in $\mathrm{Nrgl}^{f /}$ ;;Nav1.8-Cre animals at E14.5 and E16.5, indicating no difference in the rate of DRG neuron apoptosis before birth (supplemental Fig. 4, available at www.jneurosci.org as supplemental material). The innervation of the epidermis was analyzed to investigate whether abnormal axoglial signaling caused by NRG1 ablation could lead to a reduction in target innervation by sensory neurons. There was no significant difference in IENFD (fibers per millimeter) when stained for either PGP9.5, a panneuronal marker (IENFD, $35.2 \pm 6.2$ and $31.5 \pm 4.4$ in $N r g 1^{f / f}$ and $N r g 1^{f / f}$; Nav1.8-Cre animals, respectively), or CGRP (IENFD, 8.6 \pm 1 and $6.9 \pm 2.7$ in $N r g 1^{f / f}$ and $N r g 1^{f / f}$; Nav1.8-Cre animals, respectively). There remained no difference in IENFD at the age of 1 year $(27.7 \pm 2$ and $29.6 \pm 2.7$ in $N r g 1^{f / f}$ and $N r g 1^{f / f} ; N a v 1.8$-Cre animals, respectively). This indicates that, after E13, axonally derived NRG1 is not required for C-fibers to reach their target of the epidermis or maintain target innervation (Fig. 6). There was no difference in the DRG cell size distribution after NRG1 ablation (supplemental Fig. 5, available at www.jneurosci.org as supplemental material). In addition, there was no evidence for an alteration in the constituent DRG cell populations as defined histochemically: counts of DRG cell profiles stained for NF200 (a marker for large-diameter DRG cells), CGRP, and IB4 binding (markers for peptidergic and nonpeptidergic C-fibers, respectively) were unchanged (Table 2; supplemental Fig. 5, available at www.jneurosci.org as supplemental material).

\section{Altered nociceptive behavior in the absence of NRG1}

To assess the impact of NRG1 ablation on nociceptive behavior, the thermal and mechanical thresholds of $\mathrm{Nrg}^{\mathrm{f} / \mathrm{f}} ; \mathrm{Nav1.8-Cre}$ and $\mathrm{Nrg}^{\mathrm{f} / \mathrm{f}}$
B
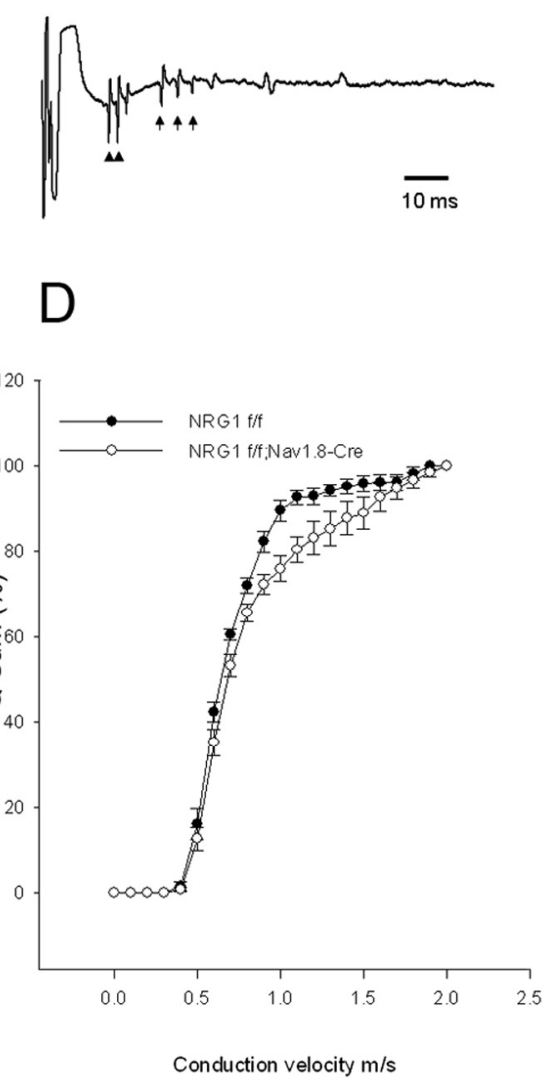

Figure 5. The CV of individual sensory axons projecting through the sciatic nerve was measured by stimulation of the nerve electrically and recording and averaging activity in fine strands of the $L 4$ dorsal root. $A$ and $B$ show representative recordings from $\mathrm{Nrg}^{\mathrm{f} / \mathrm{f}}$ and $\mathrm{Nrg} \mathrm{T}^{\mathrm{f} / \mathrm{f}}$;Nav1.8-Cre mice, respectively, after stimulation using C-fiber parameters (1 mA; $\left.1 \mathrm{~ms}\right)$. The arrows show essentially only seen in $\mathrm{Nrg}^{f / f}$;Nav1.8-Cre mice that conduct in what is normally the slower part of the A-fiber range but that

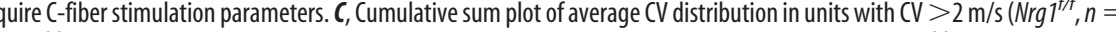
in units with $\mathrm{CV}<2 \mathrm{~m} / \mathrm{s}$. These units are significantly faster in the $\mathrm{Nrg}^{\mathrm{f} / \mathrm{f}}$; Nav1.8-Cre animals (seen as a rightward shift in Qsum plots), particularly in the $\mathrm{CV}$ range of $1-2 \mathrm{~m} / \mathrm{s}$.

mice were assessed at intervals over a period of 1 year (Fig. 7; supplemental Fig. 6, available at www.jneurosci.org as supplemental material). There was no difference in sensitivity to noxious thermal stimuli assessed using Hargreaves method at any time point. Similarly, the mechanical threshold tested by von Frey hairs was unchanged. There was an increased threshold in $\mathrm{Nrg}^{\mathrm{flf}}$; $\mathrm{Nav1.8-Cre} \mathrm{mice} \mathrm{after}$ application of a ramp pressure mechanical stimulus (using the method of Randall-Selitto), which became more apparent with age. The performance of $\mathrm{Nrgl}^{\mathrm{flf}}$; $\mathrm{Nav1.8-Cre}$ on the rotarod as well as their response to the hot-plate test and noxious cold were unchanged (supplemental Fig. 6, available at www.jneurosci.org as supplemental material).

\section{Discussion}

We found that the selective ablation of NRG1 within sensory neurons results in profound changes in the structural relationship between axons and both nonmyelinating and myelinating Schwann cells: Large numbers of clustered unmyelinated axons are observed within Remak bundles and myelination is impaired as demonstrated by a reduction in the proportion of 


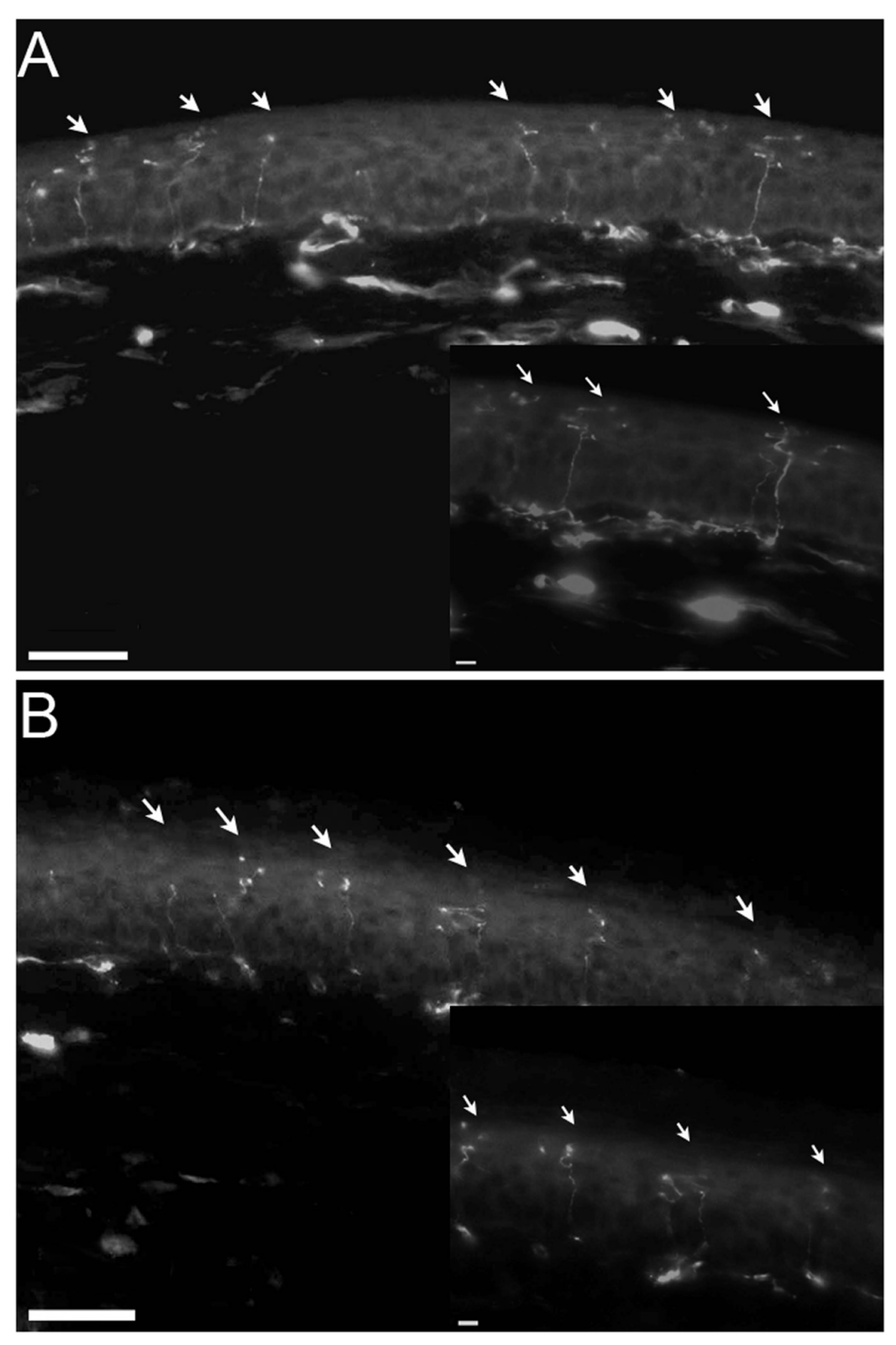

Figure 6. Cutaneous innervation is unchanged in NRG1 knock-out mice. Photomicrographs of skin sections stained for PGP9.5, a pan-neuronal marker. There is no difference in the density of fibers (arrows) in the epidermal layer in Nrg $1^{f / f} ; \operatorname{Nav1.8-Cre~mice~(B)~}$ compared with $\mathrm{Nrg}^{\mathrm{f} / \mathrm{f}}$ littermates $(\boldsymbol{A})$. The images are at $20 \times$ magnification; scale bars, $50 \mu \mathrm{m}$. The inset panel images are at $40 \times$ magnification; scale bars, $20 \mu \mathrm{m}$.

Table 2. Percentage counts of L4 DRG cell profiles immunopositive for CGRP, IB4, and NF200

\begin{tabular}{lll}
\hline & \multicolumn{2}{l}{ \% Count of immunopositive DRG profiles } \\
\cline { 2 - 3 } & $\mathrm{Nrg}^{f / f}$ & $\begin{array}{l}\mathrm{Nrg}^{f / f} ; \\
\text { Nav1.8-Cre }\end{array}$ \\
\hline IB4 & $34.35 \pm 2.1$ & $30.04 \pm 1.4$ \\
CGRP & $30.65 \pm 2.2$ & $33.00 \pm 1.5$ \\
NF200 (N52) & $31.90 \pm 2.3$ & $32.66 \pm 2.3$ \\
\hline
\end{tabular}

Note that there was no difference between in $\mathrm{Nrg}^{\text {ff/f }}$ and $\mathrm{Nrg}^{\mathrm{ff} / \mathrm{F}}$;Nav1.8-Cre mice in the percentage of DRG cell profile percentages immunopositive for these markers; $n=4$. Data are presented as mean \pm SEM.

myelinated axons and an increased $g$ ratio. These structural changes are reflected in a slowing of conduction velocity in the A-fiber conduction range and a reduced sensitivity to highthreshold mechanical stimuli. In contrast to animals that lack
NRG1 at earlier stages of development, there was no evidence of DRG cell or axon loss.

The role of NRG1 in signaling between small-diameter sensory axons and nonmyelinating Schwann cells Nrg1 ${ }^{f / f}$;Nav1.8-Cre mice demonstrated impaired sorting and ensheathment of unmyelinated axons: We found an increase in the number of axons per Remak bundle. Normally unmyelinated axons in peripheral nerves are isolated from each other by Schwann cell processes (Murinson and Griffin, 2004). After conditional NRG1 ablation there was poor segregation of unmyelinated axons that were clustered in polyaxonal pockets. We also observed instances of type 2 axon/Schwann cell relationships in which the axolemma is directly exposed to the endoneurium (Murakawa et al., 2002). A similar morphological phenotype is seen within the peripheral nerves of animals that are haploinsufficient for NRG1 type III (Taveggia et al., 2005) or in animals lacking BACE1, an enzyme that proteolytically cleaves this molecule (Willem et al., 2006). In contrast, Chen et al. (2003) used a dominantnegative erbB4 receptor expressed in NMSCs to block Neuregulin signaling and described increased Schwann cell proliferation, apoptosis, and reduced numbers of axons per Remak bundle. These differences may be attributable to the fact that in the study of Chen et al., NRG1 signaling is blocked in the postnatal period/adulthood as opposed to late embryonic development. Second, the Nrg1 ${ }^{f / f}$;Nav1.8-Cre mice selectively lack sensory axon-derived NRG1; however, there is a possibility that NRG1 may have an autocrine action on Schwann cells that would be impaired in the dominant-negative erbB4 receptor mice but not in our animals (Raabe et al., 1996; Rosenbaum et al., 1997); direct evidence for an autocrine NRG1 loop in Schwann cells is, however, lacking (Meier et al., 1999). There is also a possibility that the dominant-negative erbB4 receptor may block erbB signaling from ligands other than NRG1 within peripheral nerve.

The survival and migration of Schwann cell precursors are dependent on axonally derived NRG1 type III (Dong et al., 1995; Meyer et al., 1997; Wolpowitz et al., 2000). At later stages of development, Schwann cells develop autocrine survival circuits (Jessen and Mirsky, 2005). As expected, we observed Schwann cell apoptosis in postnatal but not in the adult nerve (Grinspan et al., 1996); however, there was no increase in the rate of Schwann cell apoptosis (at either time point) in $\mathrm{Nrg}^{f / f}$; $\mathrm{Nav1.8-Cre} \mathrm{mice.}$ Consistent with this observation, there was no significant change in the number of Schwann cell nuclei (either nonmyelinating or myelinating) within the adult sural nerve of $\mathrm{Nrg}^{1 / f / f}$; Nav1.8-Cre mice. In these animals in which the number of sural axons re- 
mains the same and there are Remak bundles containing increased numbers of unmyelinated axons, one may have expected a reduction in the number of Schwann cells. One explanation for this apparent paradox is that these animals demonstrate a new population of large-diameter axons that are in a 1:1 relationship with a Schwann cell but that have failed to be myelinated (see below). Large-diameter axons that have failed to myelinate would be expected to be associated with more Schwann cells along the length of the axon because of the shorter internuclear distance between adjacent Schwann cells associated with unmyelinated axons (Griffin and Thompson, 2008). The occurrence of such axons alongside the increase in the size of Remak bundles appears to be in balance such that the total number of Schwann cells is unchanged in $\mathrm{Nrg}^{f f}$; Nav1.8-Cre mice.

The role of NRG1 in the myelination of large-diameter sensory axons

During the development of the peripheral nervous system, the level of axonally derived NRG1 type III determines the ensheathment fate of axons and the thickness of the myelin sheath (Michailov et al., 2004; Taveggia et al., 2005). Largediameter DRG cells that are myelinated show a higher level of NRG1 type III expression (Bermingham-McDonogh et al., 1997). NRG1 does not appear to have such a critical instructive role in myelination of axons within the CNS (Taveggia et al., 2005, 2008; Roy et al., 2007; Brinkmann et al., 2008). Consistent with a role of NRG1 in the myelination of sensory axons, we found an increased proportion of unmyelinated axons in $\mathrm{Nrg}^{\mathrm{fff}} ; \mathrm{Nav1.8}$-Cre mice as well as an increase in the $g$ ratio of nerve fibers within the sural nerve. Previous studies of animals haploinsufficient for NRG1 type III (Taveggia et al., 2005) or with a dominant-negative erbB4 receptor expressed in myelinating glia (Chen et al., 2003) also found an increased $g$ ratio. The key role of NRG1 in myelination is emphasized by the observation in $\mathrm{Nrg}^{\mathrm{fff}}$; $\mathrm{Nav1.8}$-Cre mice of large-diameter sensory axons in a 1:1 relationship with a Schwann cell and surrounded by a basal lamina but that have failed to myelinate.

\section{The consequences of NRG1 ablation for the survival and functional properties of sensory neurons}

It has been suggested that NMSCs support axons in a number of ways, for instance in the provision of neurotrophic factors (Griffin and Thompson, 2008). We had therefore speculated that the increased numbers of axons per Remak bundle and the arrangement of C-fibers in polyaxonal pockets seen in $\mathrm{Nrg}^{\mathrm{fff}}$; Nav1.8-Cre mice may lead to defective axonal maintenance. Although changes in the functional properties of axons were observed, there was no evidence of axonal degeneration in these animals.

During early development of the peripheral nervous system (between E12.5 and 14.5), DRG cell survival is dependent on NRG1-mediated survival of Schwann cell precursors (Riethma-
B

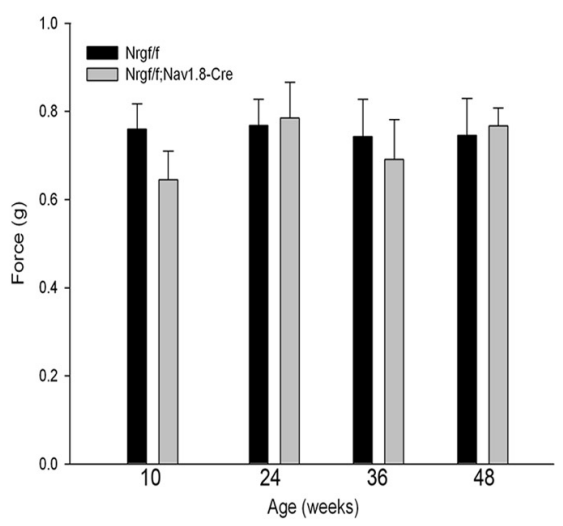

C

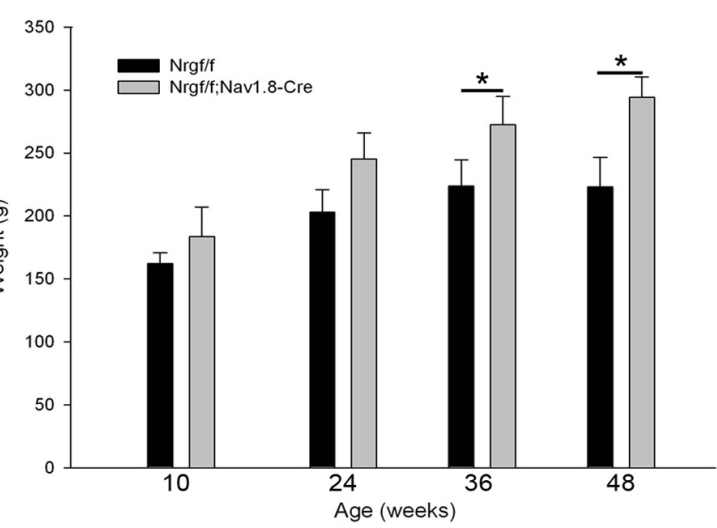

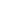

Figure 7. The nociceptive behavior of a cohort of $\mathrm{Nrg} \mathrm{T}^{\mathrm{f} / \mathrm{f}}$ and $\mathrm{Nrg} \mathrm{T}^{\mathrm{f} / f} ; \mathrm{Nav1.8}$-Cre mice was followed over the course of 48 weeks $(n=8$ per group). There was no significant difference in the response to noxious thermal stimuli as measured by Hargreaves apparatus $(\boldsymbol{A})$ or the response threshold to mechanical stimulation using von Frey hairs ( $\boldsymbol{B}$ ) (analyzed by two-way repeated-measures ANOVA). $\boldsymbol{C}$, There was a reduced sensitivity to a high-threshold mechanical pressure stimulus applied to the tail using the Randall-Sellito apparatus, which was significant at the age of 36 and 48 weeks ( ${ }^{*} p<0.05$ by two-way repeated-measures ANOVA Tukey's post hoc).

cher et al., 1997). In animals with a dominant-negative erbB4 receptor expressed in NMSCs in the postnatal period, Chen et al. (2003) described DRG cell death, reduced expression of the markers trkA and IB4 within DRG cells, and progressive reduction in sensitivity to noxious thermal stimuli (all these changes were apparent by P60). In Nrg1 fff; $\mathrm{Nav1.8-Cre} \mathrm{mice,} \mathrm{there} \mathrm{was} \mathrm{no}$ increase in DRG cell apoptosis and the total number of axons within the sural nerve was unchanged. The proportion of DRG cell profiles expressing histochemical markers for different DRG cell populations [NF200, CGRP, and IB4 (Snider and McMahon, 1998)] were the same. In addition, IENFD, which is reduced in the context of small-fiber neuropathy both in rodents (Johnson et al., 2008) and humans (McArthur et al., 1998), was unchanged. Therefore, although sensory axonally derived NRG1 is required for the formation of the normal relationship between axons and Schwann cells in peripheral nerve, unlike Chen et al. (2003) we did not find a reciprocal relationship in which it drives a signal from the NMSC back to the sensory axon required for the structural integrity and long-term survival of sensory neurons. There are clearly situations in which reciprocal interactions between C-fibers and NMSCs are critical for the maintenance of axonal integrity, as for example seen in L1-deficient mice in which defective ensheathment of unmyelinated axons leads to progressive axonal degeneration (Haney et al., 1999).

The altered axoglial relationships within $\mathrm{Nrg}^{\mathrm{ff} ;}$; Nav1.8-Cre 
mice were reflected in the electrophysiological findings in these animals. As expected (given the myelination defect in a subset of larger-diameter axons), there was a slowing in conduction velocity particularly at the lower part of the A-fiber CV range. When recording from C-fibers in $\mathrm{Nrgl}^{f / f} ; \mathrm{Nav1.8}$-Cre mice, there was a population of faster conducting C-fibers. These were found particularly in the range of $1-2 \mathrm{~m} / \mathrm{s}$ and are likely to represent largediameter axons that have failed to be myelinated and so now conduct in the C-fiber range. The poor segregation of axons by Schwann cell cytoplasm may be expected to lead to reduced electrical insulation of $\mathrm{C}$-fibers. But we did not observe any slowing of conduction or altered action potential morphology in C-fibers. On examining sensory function in $\mathrm{Nrgl}^{\mathrm{f} / \mathrm{f}} ; \mathrm{Nav1.8}$-Cre mice, we found that the sensitivity of these animals to noxious heat and cold were unchanged. The response to punctuate mechanical stimulation with von Frey hairs was also unaltered; however, the response to a noxious pressure stimulus was reduced. This may represent deficits in encoding by either $\mathrm{A} \delta$ - (some of which have myelination deficits) or C-fibers. Our failure to see a change in threshold to von Frey hair stimulation is not unexpected given that in animals in which the same population of Nav1.8 Creexpressing DRG cells are ablated the von Frey threshold is also unaltered (Abrahamsen et al., 2008).

In conclusion, axon-derived NRG1 has a key role in axoglial signaling between sensory axons and both nonmyelinating and myelinating Schwann cells necessary for normal sensory function, however is not required for the long-term maintenance of sensory axons in adulthood.

\section{References}

Abrahamsen B, Zhao J, Asante CO, Cendan CM, Marsh S, Martinez-Barbera JP, Nassar MA, Dickenson AH, Wood JN (2008) The cell and molecular basis of mechanical, cold, and inflammatory pain. Science 321:702-705.

Bermingham-McDonogh O, Xu YT, Marchionni MA, Scherer SS (1997) Neuregulin expression in PNS neurons: isoforms and regulation by target interactions. Mol Cell Neurosci 10:184-195.

Brinkmann BG, Agarwal A, Sereda MW, Garratt AN, Müller T, Wende H, Stassart RM, Nawaz S, Humml C, Velanac V, Radyushkin K, Goebbels S, Fischer TM, Franklin RJ, Lai C, Ehrenreich H, Birchmeier C, Schwab MH, Nave KA (2008) Neuregulin-1/ErbB signaling serves distinct functions in myelination of the peripheral and central nervous system. Neuron 59:581-595.

Carraway KL 3rd, Weber JL, Unger MJ, Ledesma J, Yu N, Gassmann M, Lai C (1997) Neuregulin-2, a new ligand of ErbB3/ErbB4-receptor tyrosine kinases. Nature 387:512-516.

Chen S, Rio C, Ji RR, Dikkes P, Coggeshall RE, Woolf CJ, Corfas G (2003) Disruption of ErbB receptor signaling in adult non-myelinating Schwann cells causes progressive sensory loss. Nat Neurosci 6:1186-1193.

Dixon WJ (1980) Efficient analysis of experimental observations. Annu Rev Pharmacol Toxicol 20:441-462.

Djouhri L, Fang X, Okuse K, Wood JN, Berry CM, Lawson SN (2003) The TTX-resistant sodium channel Nav1.8 (SNS/PN3): expression and correlation with membrane properties in rat nociceptive primary afferent neurons. J Physiol 550:739-752.

Dong Z, Brennan A, Liu N, Yarden Y, Lefkowitz G, Mirsky R, Jessen KR (1995) Neu differentiation factor is a neuron-glia signal and regulates survival, proliferation, and maturation of rat Schwann cell precursors. Neuron 15:585-596.

Falls DL (2003) Neuregulins: functions, forms, and signaling strategies. Exp Cell Res 284:14-30.

Falls DL, Rosen KM, Corfas G, Lane WS, Fischbach GD (1993) ARIA, a protein that stimulates acetylcholine receptor synthesis, is a member of the neu ligand family. Cell 72:801-815.

Garratt AN, Voiculescu O, Topilko P, Charnay P, Birchmeier C (2000a) A dual role of erbB2 in myelination and in expansion of the Schwann cell precursor pool. J Cell Biol 148:1035-1046.

Garratt AN, Britsch S, Birchmeier C (2000b) Neuregulin, a factor with many functions in the life of a Schwann cell. Bioessays 22:987-996.
Golding JP, Bird C, McMahon S, Cohen J (1999) Behaviour of DRG sensory neurites at the intact and injured adult rat dorsal root entry zone: postnatal neurites become paralysed, whilst injury improves the growth of embryonic neurites. Glia 26:309-323.

Goodearl AD, Davis JB, Mistry K, Minghetti L, Otsu M, Waterfield MD, Stroobant P (1993) Purification of multiple forms of glial growth factor. J Biol Chem 268:18095-18102.

Griffin JW, Thompson WJ (2008) Biology and pathology of nonmyelinating Schwann cells. Glia 56:1518-1531.

Grinspan JB, Marchionni MA, Reeves M, Coulaloglou M, Scherer SS (1996) Axonal interactions regulate Schwann cell apoptosis in developing peripheral nerve: neuregulin receptors and the role of neuregulins. J Neurosci 16:6107-6118.

Haney CA, Sahenk Z, Li C, Lemmon VP, Roder J, Trapp BD (1999) Heterophilic binding of L1 on unmyelinated sensory axons mediates Schwann cell adhesion and is required for axonal survival. J Cell Biol 146:1173-1184

Harari D, Tzahar E, Romano J, Shelly M, Pierce JH, Andrews GC, Yarden Y (1999) Neuregulin-4: a novel growth factor that acts through the ErbB-4 receptor tyrosine kinase. Oncogene 18:2681-2689.

Hargreaves K, Dubner R, Brown F, Flores C, Joris J (1988) A new and sensitive method for measuring thermal nociception in cutaneous hyperalgesia. Pain 32:77-88.

Holmes WE, Sliwkowski MX, Akita RW, Henzel WJ, Lee J, Park JW, Yansura D, Abadi N, Raab H, Lewis GD (1992) Identification of heregulin, a specific activator of p185erbB2. Science 256:1205-1210.

Hu X, Hicks CW, He W, Wong P, Macklin WB, Trapp BD, Yan R (2006) Bacel modulates myelination in the central and peripheral nervous system. Nat Neurosci 9:1520-1525.

Jessen KR, Mirsky R (2005) The origin and development of glial cells in peripheral nerves. Nat Rev Neurosci 6:671-682.

Johnson MS, Ryals JM, Wright DE (2008) Early loss of peptidergic intraepidermal nerve fibers in an STZ-induced mouse model of insensate diabetic neuropathy. Pain 140:35-47.

Jones BJ, Roberts DJ (1968) A rotarod suitable for quantitative measurements of motor incoordination in naive mice. Naunyn Schmiedebergs Arch Exp Pathol Pharmakol 259:211.

Kwan KY, Allchorne AJ, Vollrath MA, Christensen AP, Zhang DS, Woolf CJ, Corey DP (2006) TRPAl contributes to cold, mechanical, and chemical nociception but is not essential for hair-cell transduction. Neuron 50:277-289.

Lauria G, Cornblath DR, Johansson O, McArthur JC, Mellgren SI, Nolano M, Rosenberg N, Sommer C (2005) EFNS guidelines on the use of skin biopsy in the diagnosis of peripheral neuropathy. Eur J Neurol 12:747-758.

Li L, Cleary S, Mandarano MA, Long W, Birchmeier C, Jones FE (2002) The breast proto-oncogene, HRGalpha regulates epithelial proliferation and lobuloalveolar development in the mouse mammary gland. Oncogene 21:4900-4907.

Marchionni MA, Goodearl AD, Chen MS, Bermingham-McDonogh O, Kirk C, Hendricks M, Danehy F, Misumi D, Sudhalter J, Kobayashi K (1993) Glial growth factors are alternatively spliced erbB2 ligands expressed in the nervous system. Nature 362:312-318.

McArthur JC, Stocks EA, Hauer P, Cornblath DR, Griffin JW (1998) Epidermal nerve fiber density: normative reference range and diagnostic efficiency. Arch Neurol 55:1513-1520.

Meier C, Parmantier E, Brennan A, Mirsky R, Jessen KR (1999) Developing Schwann cells acquire the ability to survive without axons by establishing an autocrine circuit involving insulin-like growth factor, neurotrophin-3, and platelet-derived growth factor-BB. J Neurosci 19:3847-3859.

Meyer D, Birchmeier C (1995) Multiple essential functions of neuregulin in development. Nature 378:386-390.

Meyer D, Yamaai T, Garratt A, Riethmacher-Sonnenberg E, Kane D, Theill LE, Birchmeier C (1997) Isoform-specific expression and function of neuregulin. Development 124:3575-3586.

Michailov GV, Sereda MW, Brinkmann BG, Fischer TM, Haug B, Birchmeier C, Role L, Lai C, Schwab MH, Nave KA (2004) Axonal neuregulin-1 regulates myelin sheath thickness. Science 304:700-703.

Morris JK, Lin W, Hauser C, Marchuk Y, Getman D, Lee KF (1999) Rescue of the cardiac defect in ErbB2 mutant mice reveals essential roles of ErbB2 in peripheral nervous system development. Neuron 23:273-283. 
Murakawa Y, Zhang W, Pierson CR, Brismar T, Ostenson CG, Efendic S, Sima AA (2002) Impaired glucose tolerance and insulinopenia in the GK-rat causes peripheral neuropathy. Diabetes Metab Res Rev 18:473-483.

Murinson BB, Griffin JW (2004) C-fiber structure varies with location in peripheral nerve. J Neuropathol Exp Neurol 63:246-254.

Nave KA, Salzer JL (2006) Axonal regulation of myelination by neuregulin 1. Curr Opin Neurobiol 16:492-500.

Peles E, Bacus SS, Koski RA, Lu HS, Wen D, Ogden SG, Levy RB, Yarden Y (1992) Isolation of the neu/HER-2 stimulatory ligand: a 44 kd glycoprotein that induces differentiation of mammary tumor cells. Cell 69:205-216.

Raabe TD, Clive DR, Neuberger TJ, Wen D, DeVries GH (1996) Cultured neonatal Schwann cells contain and secrete neuregulins. J Neurosci Res 46:263-270.

Riethmacher D, Sonnenberg-Riethmacher E, Brinkmann V, Yamaai T, Lewin GR, Birchmeier C (1997) Severe neuropathies in mice with targeted mutations in the ErbB3 receptor. Nature 389:725-730.

Rosenbaum C, Karyala S, Marchionni MA, Kim HA, Krasnoselsky AL, Happel B, Isaacs I, Brackenbury R, Ratner N (1997) Schwann cells express NDF and SMDF/n-ARIA mRNAs, secrete neuregulin, and show constitutive activation of erbB3 receptors: evidence for a neuregulin autocrine loop. Exp Neurol 148:604-615.

Roy K, Murtie JC, El-Khodor BF, Edgar N, Sardi SP, Hooks BM, BenoitMarand M, Chen C, Moore H, O’Donnell P, Brunner D, Corfas G (2007) Loss of erbB signaling in oligodendrocytes alters myelin and dopaminergic function, a potential mechanism for neuropsychiatric disorders. Proc Natl Acad Sci U S A 104:8131-8136.

Sharghi-Namini S, Turmaine M, Meier C, Sahni V, Umehara F, Jessen KR, Mirsky R (2006) The structural and functional integrity of peripheral nerves depends on the glial-derived signal desert hedgehog. J Neurosci 26:6364-6376.

Snider WD, McMahon SB (1998) Tackling pain at the source: new ideas about nociceptors. Neuron 20:629-632.

Stirling LC, Forlani G, Baker MD, Wood JN, Matthews EA, Dickenson AH, Nassar MA (2005) Nociceptor-specific gene deletion using heterozygous NaV1.8-Cre recombinase mice. Pain 113:27-36.
Takesue EI, Schaefer W, Jukniewicz E (1969) Modification of the RandallSelitto analgesic apparatus. J Pharm Pharmacol 21:788-789.

Taveggia C, Zanazzi G, Petrylak A, Yano H, Rosenbluth J, Einheber S, Xu X, Esper RM, Loeb JA, Shrager P, Chao MV, Falls DL, Role L, Salzer JL (2005) Neuregulin-1 type III determines the ensheathment fate of axons. Neuron 47:681-694.

Taveggia C, Thaker P, Petrylak A, Caporaso GL, Toews A, Falls DL, Einheber S, Salzer JL (2008) Type III neuregulin-1 promotes oligodendrocyte myelination. Glia 56:284-293.

Wen D, Peles E, Cupples R, Suggs SV, Bacus SS, Luo Y, Trail G, Hu S, Silbiger SM, Levy RB (1992) Neu differentiation factor: a transmembrane glycoprotein containing an EGF domain and an immunoglobulin homology unit. Cell 69:559-572.

Wen D, Suggs SV, Karunagaran D, Liu N, Cupples RL, Luo Y, Janssen AM, Ben-Baruch N, Trollinger DB, Jacobsen VL (1994) Structural and functional aspects of the multiplicity of Neu differentiation factors. Mol Cell Biol 14:1909-1919.

White FA, Keller-Peck CR, Knudson CM, Korsmeyer SJ, Snider WD (1998) Widespread elimination of naturally occurring neuronal death in Baxdeficient mice. J Neurosci 18:1428-1439.

Willem M, Garratt AN, Novak B, Citron M, Kaufmann S, Rittger A, DeStrooper B, Saftig P, Birchmeier C, Haass C (2006) Control of peripheral nerve myelination by the beta-secretase BACE1. Science 314:664-666.

Woldeyesus MT, Britsch S, Riethmacher D, Xu L, Sonnenberg-Riethmacher E, Abou-Rebyeh F, Harvey R, Caroni P, Birchmeier C (1999) Peripheral nervous system defects in erbB2 mutants following genetic rescue of heart development. Genes Dev 13:2538-2548.

Wolpowitz D, Mason TB, Dietrich P, Mendelsohn M, Talmage DA, Role LW (2000) Cysteine-rich domain isoforms of the neuregulin-1 gene are required for maintenance of peripheral synapses. Neuron 25:79-91.

Yang X, Arber S, William C, Li L, Tanabe Y, Jessell TM, Birchmeier C, Burden SJ (2001) Patterning of muscle acetylcholine receptor gene expression in the absence of motor innervation. Neuron 30:399-410.

Zhang D, Sliwkowski MX, Mark M, Frantz G, Akita R, Sun Y, Hillan K, Crowley C, Brush J, Godowski PJ (1997) Neuregulin-3 (NRG3): a novel neural tissue-enriched protein that binds and activates ErbB4. Proc Natl Acad Sci U S A 94:9562-9567. 